\title{
Epigenetics in Cancer: The Myelodysplastic Syndrome as a Model to Study Epigenetic Alterations as Diagnostic and Prognostic Biomarkers
}

\author{
Teresa de Souza Fernandez ${ }^{1}$ \\ André Mencalha ${ }^{1}$ and Cecília de Souza Fernandez ${ }^{2}$ \\ ${ }^{1}$ National Cancer Institute (INCA), \\ Bone Marrow Transplantation Center (CEMO) Laboratory Division, \\ Rio de Janeiro, RJ, \\ ${ }^{2}$ Mathematics and Statistics Institute, \\ Federal Fluminense University (UFF), Niterói, RJ, \\ Brazil
}

\section{Introduction}

Epigenetics is characterized as hereditary changes in gene activity and expression that occur without alteration in DNA genomic sequence. It is known that epigenetics corresponds basically by two majority modifications: DNA methylation and histone modifications. Epigenetics events are reversible without primary DNA base sequence changes, resulting in possible modulation of the gene expression. The accurate DNA modifications and chromatin changes are important to normal embryonic development, to correct tissue cells differentiation, to precise cell cycle progression and cell death control. However, since epigenetics is also crucial to regulate gene expression, uncontrolled and/or incorrect modifications can unbalance the genetic expression profile and result in cellular transformation from normal to malignant cells.

The development of cancer cell is frequently associated with sequential of genetic and/or epigenetics hits, resulting in loss- or gain-of-function in genes, which leads to cell transformation. At a glance, aberrant global levels of histone modifications as well as incorrect methylation gene promoter may lead to the silencing of tumor suppressor genes and the activation of proto-oncogenes. Recently, many studies have revealed how epigenetics regulation has an implication in the identification of new biomarkers and the development of new therapies at several types of cancers. Moreover, nowadays, a series of identified epigenetics changes have been used as markers for cancer progression and for given prognostic value.

The field of cancer epigenetics is evolving rapidly in many aspects. In myelodysplastic syndrome (MDS), some research groups have been showed the importance to study epigenetic alterations as new diagnostic, prognostic and risk stratification biomarkers. The 
MDS comprises a heterogeneous group of clonal bone marrow disorders characterized by varying degrees of pancytopenia, morphological and functional abnormalities of hematopoietic cells and increased risk of transformation into acute myeloid leukemia. This hematologic malignancy became a model to study the genetics and epigenetics changes involved in development stages of leukemia and it is considered a model study to tumorigenesis. MDS is viewed as a disease of adults, particularly the elderly. Pediatric MDS is an uncommon disorder, accounting for less than $5 \%$ of hematopoietic malignancies. Some studies in children showed that MDS appears with distinct clinical and laboratory characteristics when compared with adults, which may reflect special biological issues of MDS during childhood. There are different pathways involved in the pathogenesis of MDS. Due to the MDS heterogeneity, little is known about the molecular basis of MDS in adults and mainly in pediatric patients. Identification of the underlying genetic and epigenetic alterations in MDS may promote proper classification and prognostication of disease and, eventually, the development of new therapies. An important point in the epigenetic studies is the introduction of new forms of treatment for MDS patients. It is well documented that hematopoetic stem cell transplantation (HSCT) is, until now, the only curative treatment for MDS, both in adults and in children, but relapse after HSCT is the major cause of treatment failure in advanced stages. Other important factors in HSCT are the necessity of histocompatibility of donor cells and the age of the patients, sometimes limiting the use of this treatment. Thus, it is extremely important detecting biomarkers of disease evolution, especially those involved in epigenetic modifications, because news forms of treatment, as the use of hypomethylation agents, can be introduced as a better treatment option.

This chapter will review the advances in the study of epigenetics in cancer, the discovery of new epigenetic biomarkers and the development of therapeutic strategies using hypomethylation drugs. We will focus the advances in the epigenetic field using the myelodysplastic syndrome as a model, since it was demonstrated the importance of epigenetics alterations in the pathogenesis of this disease. Finally, we will describe the importance of statistical methods to aid the analysis of new diagnostic and prognostic epigenetic biomarkers.

\section{The role of epigenetics in cancer}

Epigenetics alterations have been growing as a promisor tool to understand cancer development, for better clinical therapy management, to identify new cancer biomarkers, which can help in monitoring disease evolution. It is known that epigenetics corresponds basically by two majority modifications: DNA methylation and chromatin modifications.

DNA methylation is a covalent modification of the cytosine ring $5^{\prime}$ position of a CpG dinucleotide, whereby a methyl group is deposited on carbon 5 of that ring using Sadenosyl methionine as a methyl donor. This transfer of methyl group is a replicationdependent reaction catalyzed by DNA methyltrasferases (DNMTs) (Figure 1).

Humans DNA methyltransferases are represented basically by three proteins: DNMT1, DNMT3A and DNMT3B. In general, DNMT1 are preferentially responsible for the methylation of one strand of DNA using as reference the other strand already methylated, mechanisms known as de novo methylation. This DNA hemi-methylation activity is important to maintain the methylation profile of genomic DNA cells during cellular 


\section{SAM-CH3 SAM}

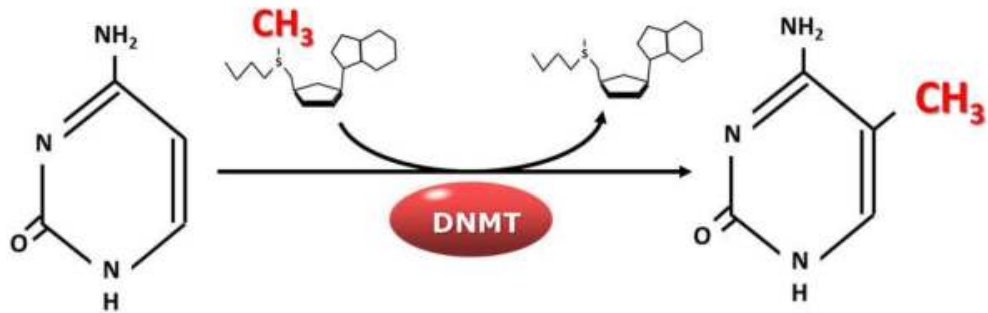

Cytosine

5-Methyl-Cytosine

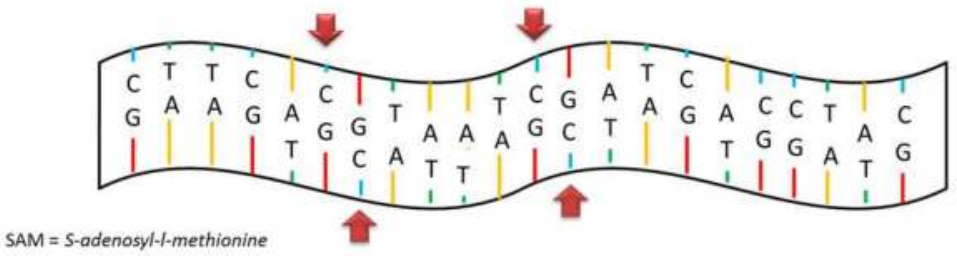

Fig. 1. DNA methylation. (A) Methyl radical transference from SAM (S-adenosyl-1methionine) to $5^{\text {th }}$ carbon of aromatic ring of cytosine nucleotide mediated by DNMT (DNA methyltransferase). (B) DNA sequence indicating that only cytosines before guanine will be methylate (red arrows). This cytosine/guanine in the methylation studies is also known as $\mathrm{CpG}$ and the concentration of $\mathrm{CpG}$ in some region of DNA sequence is known as $\mathrm{CpG}$ Island.

division. DNA hemi-methylation promoted by DNMT1 is crucial for initial stages of embryonic development and cell survival. In other hand, DNMT3A and DNMT3B play essential role for DNA hemi-methylation or unmethylated with the same level. Catalytic methyl-transferase of DNMT3A or DNMT3B is mainly promoted in cytosine preceded by guanine at the $\mathrm{CpG}$ dinucleotide. DNA methylation is a no random phenomenon. It normally occurs at the CG rich DNA sequences (the CpG islands) at promoter regions (Robertson et al., 1999; Tabby \& Issa, 2010; Worn \& Gulberg, 2002).

DNA methylation is frequently associated to transcriptional gene repression. It has been suggested that repression occurs by physically interfering in transcriptional factors binding at gene promoter regions, modified by $5^{\prime}$-methylcitosine or by recruiting methylated-DNA binding domain (MBD) proteins that block an original site of transcriptional factor. In addition, MBD proteins are frequently found associated with histone deacetylases. Physiological DNA methylation has been shown important to regulate genetic expression during embryonic development, genomic imprinting, $\mathrm{X}$ chromosome inactivation and cancer (Worn \& Gulberg, 2002).

Chromatin is defined by a DNA and DNA-associated proteins, known as histones, in which genomic eukaryotic DNA is packaged. The basic unit of chromatin is called nucleosome, which is composed of a small DNA sequence, approximately 147 bases pairs, wrapped on 
protein octamer of the four core Histones (H2A, H2B, H3, and H4) and linker Histone H1. Epigenetics regulation involving chromatin comprises the post-translational modifications of histone protein tails. Depending on the kind of histone alteration, chromatin becomes compressed or weakens, which results in repression or permission to gene expression respectively. The histone complexes can be heterogeneous post-translational modified; it comprises methylation, acetylation, phosphorylation and ubiquitinylation. These distinct levels of combinatory histone modifications possibilities lead to regulation of gene transcription, a process called "histone coding". These histone changes are promoted by a series of distinct proteins, such as histone acetyl transferases (HAT), histone deacetylases (HDAC) and Polycomb group (PcG) proteins (Marks \& Dokmanovic, 2005). The HAT and HDAC catalyze the transference of acetyl radical to histone tails (Kleff et al., 1995). Commonly, chromatin acetylation promotes the transcription factors access to DNA consensus sequences. Therefore, chromatin acetylation is frequently related to increase of transcriptional gene activity (Figure 2). Acetylation is not a random event and occurs in $\mathrm{H} 3$ and H4 tails, mainly on lysine residue, such as H3K4 and H3K14 (Agalioti et al., 2002).
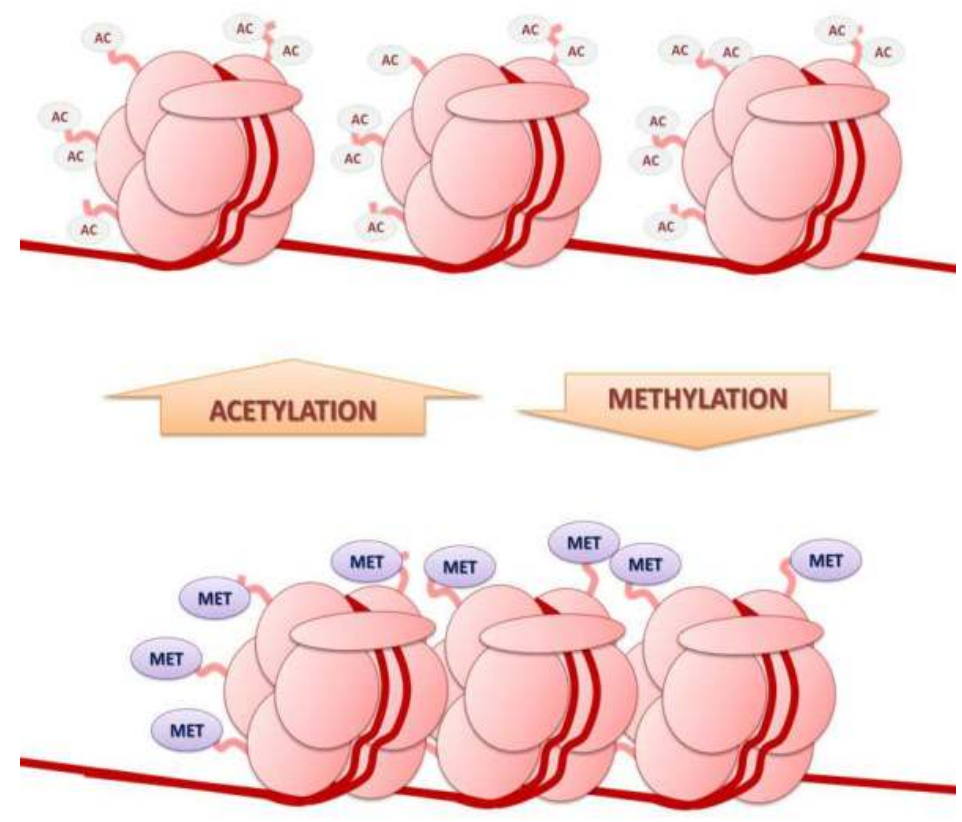

Fig. 2. Chromatin structure and histone tails modifications. Two mainly chromatin modifications, acetylation (AC) and methylation (MET). Acetylation is direct related to loose of chromatin compression which allows transcriptional factors access to DNA molecule and transcript its target gene. Methylation of histone tails is associated to chromatin compression and, as consequence, block the transcriptional factors access.

Among chromatin modifiers, Polycomb Group (PcG) proteins have been established as classical players of epigenetics regulation. PcG genes were discovered at experiments of mutations in Drosophila development (Lewis, 1978). In these studies, PcG proteins were 
found to control the activities of homeotic genes, which determine segmentation and structures body during development (Ingham, 1985). Several PcG orthologues genes were found in humans (van Lohuizen et al., 1991). PcG proteins are subdivided into two classes designed as Polycomb Repressive Complex: PRC1 and PRC2. The number of PcG proteins suggests a greater complexity of functions on the chromatin regulating. In this context, PcG have been reported to act in a myriad of histone modifications such as, ubiquitylation, sumoylation and methylation (Margueron \& Reinberg, 2005). PcG proteins perform a critical role in gene regulation. PCR2 and PCR1 are considered to be involved in the initialization and maintenance of the repression of the gene transcription, respectively. PCR2 comprises the core components enhancer of zeste-2 (EZH2), embryonic ectoderm development (EED), and suppressor of zeste 12 (SUZ12), while PCR1 consists in a ring finger protein 1 (RING1), B lymphoma Mo-MLV insertion region 1 (BMI1) and chromobox homologue 2/4/8 (CBX2/4/8). EZH2 is the catalytic subunit of PRC2. It is a highly conserved histone methyltransferase that targets lysine 27 of histone H3. This methylated H3-K27 is usually associated with silencing of genes involved in differentiation. In addition, EZH2 is required for DNA methylation of EZH2- target promoters, serving as a recruitment platform DNA methyltransferases. SUZ12 is a recently identified PcG protein that, together with EED, is essential to maintaining the repressive function of PRC2. RING1 catalyzes the mono ubiquitylation of histone H2A at lysine 119. The H2AK 119 ubiquitylation likely increases chromatin compaction and, thus, interferes with the access or action of transcription factors. BMI 1 is mostly detected in stem cells and progenitors and takes part in stem cell proliferation and self-renewal (Bantignies \& Cavalli, 2006; Levine et al., 2004; Rajasekhar \& Begemann, 2007).

Cancer development is a consequence of multi-step molecular and cellular events that transform normal to malignant cell. During this process genetic and epigenetic alterations are involved. In recent years, several studies have indicated how epigenetics regulation has an implication in the identification of new biomarkers and the development of new therapies in a majority of cancers. Several evidences of oncogenes and tumor supressor genes DNA methylation indicated the importance of these epigenetics changes under expression control. DNA hypomethylation was directly related to the overexpression of Raf, c-Myc, c-Fos, c-H-Ras and c-K-ras oncogenes and tumor liver formation (Rao et al., 1989). Hypermethylation of tumor suppressor genes has also been demonstrated. For example, DNA methylation interferes in the expression of key cell cycle checkpoints genes: $p 16^{I N K 4 A}$, $p 15$ INK4B, $R b, p 14 A R F$. These are the most studied genes used to correlate methylation and cell cycle control in several cancer types (Esteller, 2011). DNA or chromatin epigenetic alterations have been directly related to molecular changes to cancer development. Some epigenenetic modifications have been usefulness as biomarkers to aid in the clinicaltherapeutic decision. For instance, APC and GSTP1 gene methylation and H3K4me/H3K4me2/H3K18Ac chromatin modifications have been used to predict response to therapy and prognostic information in prostate cancer (Henrique \& Jerónimo, 2004; Jerónimo et al., 2011).

The potential reversibility of epigenetics states offers exciting opportunities for new cancer drugs that can reactivate epigenetically silenced tumor-suppressor genes. Blocking either DNA methyltransferases or histone deacetylase activity could potentially inhibit or reverse the process of epigenetic silencing (Kelley et al., 2010). DNA demethylating drugs (DMI), as 
5-azacytidine and 5-aza-2'-deoxycytidine, have been indicated as a promising new treatment for cancer (Streseman \& Lyko, 2008). Histone deacetylase inihibitors (HDACs) have also been analyzed at clinical protocols for solid tumors (breast, non-small lung cells, prostatic cancer) and mainly for hematological malignancies (myelomas, leukemias and myelodysplastic syndrome) (Ellis et al., 2009; Graham et al., 2009; Hrebackova et al., 2010; Razak et al., 2011). In figure 3, we can see that the epigenetic therapy can "re-programmed" gene expression patterns.

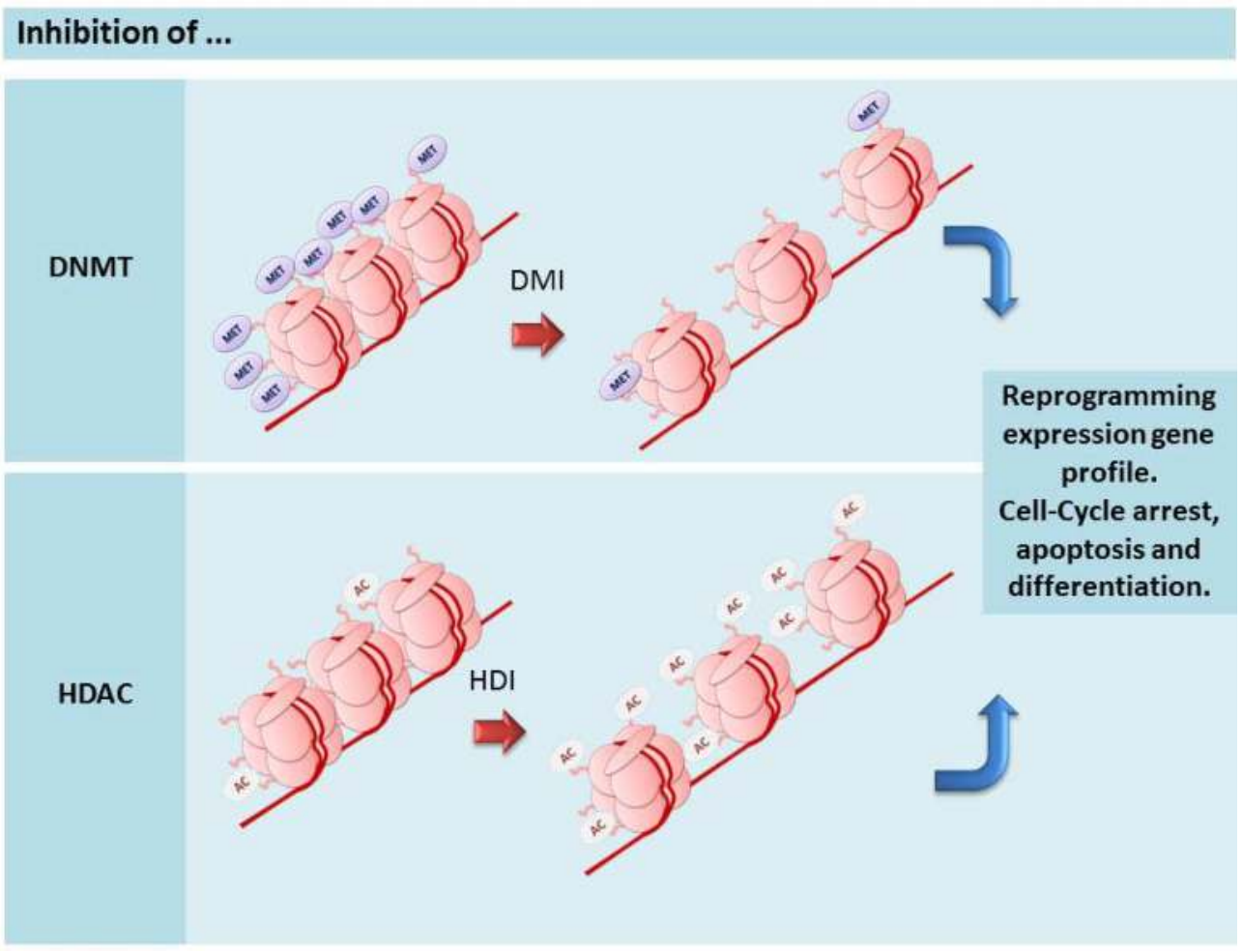

Fig. 3. Epigenetic therapy acting in the effects of DNMT or HDAC. Inhibitors of DNMT (DNA methyltransferase) or HDAC (histone deacetylases), as DMI (DNMT inhibitor) and HDI (Histone Deacetylase Inhibitor), respectively, induce the reprogramming expression by chromatin decompression. In summary, these inhibitors act mainly cell-cycle, apoptosis and differentiation related genes.

\section{Myelodysplastic syndrome}

The primary myelodysplastic syndrome (MDS) comprises a heterogeneous group of clonal bone marrow disorders, characterized by abnormal cellular morphology (dysplasias) and defects in the normal differentiation and prolileration of hematopoietic precursors. These 
defects result in ineffective hematopoiesis (bone marrow failure) and an increased risk of transformation into acute myeloid leukemia (AML) (Davids \& Steensma, 2010; Jadersten \& Hellström-Lindberg, 2008). MDS is viewed as a disease of adults, particularly the elderly. Pediatric MDS is an uncommon disorder, accounting for less than $5 \%$ of hematopoietic malignancies (Elghetany, 2007; Niemeyer \& Baumann, 2008). The primary MDS presents a natural history since an indolent disease with long time of duration to a rapid progression to AML in few months (Nishino \& Chang, 2005). The diagnosis is done initially by the hemogram indicating one or more cytopenias in peripheral blood like anemia, neutropenia and thrombocytopenia. The analysis is performed by the myelogram and bone marrow biopsy to identify dysplastic cells, the possible presence of blasts, characterizing later stages of the disease, and the presence of abnormal localization of immature precursors (ALIP). The bone marrow of MDS patients is usually hypercellular or normocellular, but there are a small number of cases with hypocellular bone marrow. In cases where bone marrow is hypocellular, it is recommended to perform differential diagnosis of severe aplastic anemia (SAA) and paroxysmal nocturnal hemoglobinuria (PNH). In these cases, important diagnostic tools, like the cytogenetics and the immunophenotyping, aid this diagnosis (Bennett \& Orazi, 2009; Wong \& So, 2002). The apparent paradox of hypercellular bone marrow and peripheral blood cytopenias was clarified by studies showing that MDS patients have increased rates of apoptosis in bone marrow in early stages of the disease (Parker et al., 2000).

The primary MDS diagnosis is considered a difficult clinical practice, because there are several clinical manifestations which may present a clinical and histological picture quite similar to MDS, such as nutritional deficiencies, infections and congenital conditions. It is necessary a differential diagnosis, where the presence of cytogenetic clonality helps in the diagnosis of primary MDS and contributes for the prognosis (Haase et al., 2007; Olney \& Le Beau, 2009; Solé et al., 2005; Tiu et al., 2011). Nevertheless, there are cases with normal karyotype, so it is important to characterize molecular biomarkers to aid the MDS diagnosis. Because the primary MDS is a disease extremely heterogeneous, the definition of prognostic factors are often difficult. Thus, in the later years, it has been extensively discussed the classifications and prognostic scales for adult and pediatric patients.

\subsection{Classifications and prognostic scores systems in myelodysplastic syndrome}

Until 1980, the MDS included a variety of hematologic abnormalities classified as syndromes or pre-leukemic states. However, these denominations were unsatisfactory, not grouping all the patients who showed an ineffective hematopoiesis and not progressed to acute leukemia, occurring complications because of the cytopenias leading to death. The term "pre-leukemia" disappeared and the term myelodysplstic syndrome became widely accepted in 1982 with the FAB classification.

\subsubsection{FAB classification}

In 1982, the FAB group (French, American and British group) proposed a classification for primary MDS into five subgroups: refractory anemia (RA), refractory anemia with ringed sideroblasts (RARS), refractory anemia with excess blasts (RAEB), refractory anemia with excess blasts in transformation (RAEB-t) and chronic myelomonocytic leukemia (CMML). 
This classification was based on morphological characteristics and the percentage of blasts in the bone marrow and peripheral blood (Table 1) (Bennett et al., 1982).

\begin{tabular}{|c|c|c|c|c|c|}
\hline & & & \multicolumn{2}{|c|}{ Blast cells (\%) } & \multirow{2}{*}{$\begin{array}{c}\text { Auer } \\
\text { rods } \\
\text { bubgroup }\end{array}$} \\
\cline { 4 - 6 } & Monocytes $(\mu \mathrm{l})$ & \multirow{2}{*}{$\begin{array}{c}\text { Ringed Sideroblasts } \\
\text { peripheral blood }\end{array}$} & $\begin{array}{c}\text { (\%) bone marrow } \\
\text { peripheral } \\
\text { blood }\end{array}$ & $\begin{array}{c}\text { bone } \\
\text { marrow }\end{array}$ & marrow \\
\hline RA & No & $<15$ & $<1$ & $<5$ & No \\
\hline RARS & No & $>15$ & $<1$ & $<5$ & No \\
\hline RAEB & No & No & $<5$ & $5-20$ & No \\
\hline RAEB-t & No & No & $>5$ & $20-30$ & Yes or No \\
\hline CMML & $>1000$ & No & $<5$ & $<20$ & No \\
\hline
\end{tabular}

Table 1. Classification of Myelodysplastic Syndrome according to the FAB Group in 1982.

As we can notice, this classification suggests multiple steps during the evolution from MDS to acute leukemia, being the initial stages the RA and RARS and the advanced stages the RAEB, RAEB-t and CMML. Since it was introduced, several studies have shown the usefulness of the FAB classification, both for monitoring a large number of patients with primary MDS, allowing comparisons between different studies, as for the treatment of patients. However, to determine a precise prognosis this classification still has some problems especially within initial subgroups, RA and RARS. The term "refractory anemia" is not always adequate, and anemia is only one of the three cytopenias in MDS. The CMML presents features of MDS and myeloproliferative diseases, so their inclusion in MDS classification has been discussed in more recent classifications like the World Health Organization (WHO) (Harris et al., 2000; Malcovati \& Nimer, 2008).

\subsubsection{WHO classification}

The classification of the World Health Organization (WHO) was established in 2000 and used many concepts and definitions of the FAB classification and also the knowledge of the cytogenetic and molecular features to improve the definition of subgroups, as well as clinical relevance in order to improve diagnostic criteria and improve the prognosis definition (Harris et al., 2000). The main difference between the two classifications is the disappearance of the subgroup RAEB-t, considered the evolution to AML from 20\% of blasts in the bone marrow. The classification system proposed by WHO was reviewed in 2008 and consider the subgroups described in Table 2. In this new classification the subgroup CMML is regarded as a myeloproliferative disorder. The WHO categories have several important clinical implications (Brunning et al., 2008). Patients with unilineage dysplasia have a favorable outcome compared to patients with multilineage dysplasia (Jadersten \& Hellstrom, 2008). The presence of $\operatorname{del}(5 q)$ strongly correlates to the probability of response to lenalidomide (Oliva et al., 2010). 


\begin{tabular}{|c|c|c|}
\hline Subgroup & Peripheral Blood & Bone marrow \\
\hline $\begin{array}{l}\text { Refractory cytopenias } \\
\text { with unilineage } \\
\text { dysplasia (RCUD) }\end{array}$ & $\begin{array}{l}\text { Unicytopenia or } \\
\text { bicytopenia; } \\
\text { No or rare blasts }(<1 \%)\end{array}$ & $\begin{array}{l}\text { Unilineage dysplasia; } \\
\geq 10 \% \text { of the cells of the affected lineage } \\
\text { are dysplastic; }<5 \% \text { blasts; } \\
<15 \% \text { ring sideroblasts }\end{array}$ \\
\hline $\begin{array}{l}\text { Refractory anemia } \\
\text { with ring sideroblasts } \\
\text { (RARS) }\end{array}$ & $\begin{array}{l}\text { Anemia; } \\
\text { No blasts }\end{array}$ & $\begin{array}{l}\text { Erythroid dysplasia only; } \\
<5 \% \text { blasts; } \\
\geq 15 \% \text { ringed sideroblasts }\end{array}$ \\
\hline $\begin{array}{l}\text { Refractory cytopenia } \\
\text { with multilineage } \\
\text { dysplasia (RCMD) }\end{array}$ & $\begin{array}{l}\text { Cytopenia(s); } \\
\text { or rare blasts }(<1 \%) ; \\
\text { No Auer rods; } \\
\text { monocytes }<1 \times 10^{9} / \mathrm{L}\end{array}$ & $\begin{array}{l}\text { Dysplasia in } \geq 10 \% \text { of cells in two or } \\
\text { more myeloid lineages; } \\
<5 \% \text { blasts; } \\
\text { No Auer rods; } \\
\pm 15 \% \text { ring sideroblasts } \\
\end{array}$ \\
\hline $\begin{array}{l}\text { Refractory anemia } \\
\text { with excess blasts-1 } \\
\text { (RAEB-1) }\end{array}$ & $\begin{array}{l}\text { Cytopenias; } \\
<5 \% \text { blasts; } \\
\text { No Auer rods; } \\
\text { monocytes }<1 \times 10^{9} / \mathrm{L}\end{array}$ & $\begin{array}{l}\text { Unilineage or multilineage dysplasia; } \\
5-9 \% \text { blasts; } \\
\text { No Auer rods }\end{array}$ \\
\hline $\begin{array}{l}\text { Refractory anemia } \\
\text { with excess blasts-2 } \\
\text { (RAEB-2) }\end{array}$ & $\begin{array}{l}\text { Cytopenias; } \\
\text { 5-19\% blasts; } \\
\pm \text { Auer rods; } \\
\text { monocytes }<1 \times 109 / \mathrm{L}\end{array}$ & $\begin{array}{l}\text { Unilineage or multilineage dysplasia; } \\
10-19 \% \text { blasts; } \\
\pm \text { Auer rods }\end{array}$ \\
\hline Syndrome 5q- & $\begin{array}{l}\text { Anemia; } \\
\text { No or rare blasts }(<1 \%) ; \\
\text { Platelet count usually } \\
\text { normal or increased }\end{array}$ & $\begin{array}{l}\text { Normal to increased megakaryocytes } \\
\text { with hypolobated nuclei; } \\
<5 \% \text { blasts; } \\
\text { Isolated del( } 5 q) \text { cytogenetic } \\
\text { abnormality; } \\
\text { No Auer rods }\end{array}$ \\
\hline $\begin{array}{l}\text { Myelodysplastic } \\
\text { syndrome, } \\
\text { unclassified (MDS-U) }\end{array}$ & $\begin{array}{l}\text { Cytopenias; } \\
\text { Blasts } \leq 1 \%\end{array}$ & $\begin{array}{l}\text { Dysplasia in }<10 \% \text { of the cells in one or } \\
\text { more myeloid lineages; } \\
<5 \% \text { blasts; } \\
\text { No Auer rods }\end{array}$ \\
\hline
\end{tabular}

Table 2. The WHO 2008 Classification of MDS.

\subsubsection{Classification of myelodysplastic syndrome in childhood}

Some studies have shown differences in morphological, cytogenetic, molecular and clinical manifestations of primary MDS in childhood that affect their inclusion in traditional classification systems (FAB and WHO), based mainly on adult patients. The rarity of childhood MDS and the heterogeneous nature of the disease have further contributed to the difficulties in classifying this disease (Hasle \&Niemeyer, 2011). In 2003, Hasle and colleagues proposed a pediatric approach to the WHO classification of myelodysplastic syndrome: 1- MDS occurring both "de novo" and secondary, including the subtypes refractory cytopenia (RC), RAEB, and RAEB-t.; 2- a group of myelodysplastic/ myeloproliferative disorders with Juvenile Myelomonocytic Leukemia (JMML) as the most common disorder of this category; 3- myeloid leukemia of Down syndrome (DS), a disease with distinct clinical and biological features, encompassing both MDS and AML. In this classification, the minimal diagnostic criteria are: unexplained cytopenia (neutropenia, 
thrombocytopenia or anemia), at least bilineage morphologic myelodysplasia, acquired clonal cytogenetic abnormality in hematopoietic cells and blast cells number $\geq 5 \%$. However, this classification has also been widely discussed because not all patients have chromosomal abnormalities, especially in the early stages of the disease (Niemeyer \& Baumann, 2008). And in 2009, JMML was considered a myeloproliferative disorder (Hebeda \& Fend, 2009).

\subsubsection{Prognostic score system in myelodysplastic syndrome}

Parallel to the improvement of classification systems, due to the large variability in survival within the same subgroup of primary MDS, it was necessary to develop score systems for prognostic stratification of risk groups, assisting the choice of treatment. The score system for risk groups most widely used for primary MDS is the International Prognostic Score System (IPSS) (Greenberg et al., 1997). The IPSS considers the percentage of bone marrow blasts, the number of peripheral blood cytopenias and the cytogenetic, the prognostic factors most important in relation to survival time and about the rate of leukemic transformation. The IPSS recognized four risk groups: low risk, intermediate 1, intermediate 2 and high risk. This system considers three categories for cytogenetic analysis: low risk [normal karyotypes, $-Y$, del(5q) and del(20q)]; high risk (alterations involving chromosome 7 and complex karyotypes) and intermediate risk (other chromosome abnormalities) .

The IPSS has gained prominence for its clinical utility due to the fact that it allows the prediction of disease progression in independent series of previously untreated patients. However, despite its importance, this system has some limitations like the risk groups in relation to karyotype. In some studies, trisomy 8 , for example, is often associated with disease progression (Fernandez et al., 2000; Garcia-Manero, 2010; Solé et al., 2000). However, the IPSS classifies this chromosomal alteration with intermediate prognosis. Other important point is related to normal karyotypes that are associated, in some cases, to shorter survival when compared to some chromosomal alterations like: $-X, \operatorname{del}(5 q), \operatorname{del}(20 q),+21$ (Haase, 2008). So, the introduction of molecular data will help to characterize new prognostic factors and use these biomarkers to contribute in understanding the development of MDS and its evolution to AML.

\subsection{Pediatric and adult myelodysplastic syndrome}

Although the pediatric MDS shows dysplastic features and ineffective hematopoiesis, such as MDS in adults, clinical characteristics, the presence of constitucional genetic associated abnormalities and characterization of chromosomal changes have reflected a different biological question of MDS in childhood (Elghetany, 2007; Polychronopoulou et al., 2004). The main differences between childhood and adult MDS are: the incidence of RARS cases are extremely rare in pediatric patients and in adults consists of about $25 \%$ of cases; the monosomy 7 is the chromosomal alteration most frequent in pediatric patients and in adults is the deletion of the long arm of chromosome 5; the therapeutic possibilities in adult patients is generally limited due to advanced age and usually it is indicated a palliative therapy, whereas, in children with MDS, the main therapy indicated is curative; the allogeneic hematopoetic stem cell transplantation (Halse \& Niemeyer, 2002). Some clinical features are different between adults and children with MDS and the factors that predict survival or progression in adults are of little value to children. So, the IPSS has limited value for pediatric MDS (Hasle et al., 2004). 
In relation to cytogenetic studies, they showed a key role in the diagnosis of the suspected cases of pediatric MDS, being used to confirm the clonal nature of this disease (Sasaki et al., 2001). The monosomy 7 is the most common chromosomal abnormality in these patients (Figure 4). This alteration is associated with poor prognosis and a rapid progression to AML (Aktas et al., 2006; Fernandez et al., 2000; Sasaki et al., 2001).
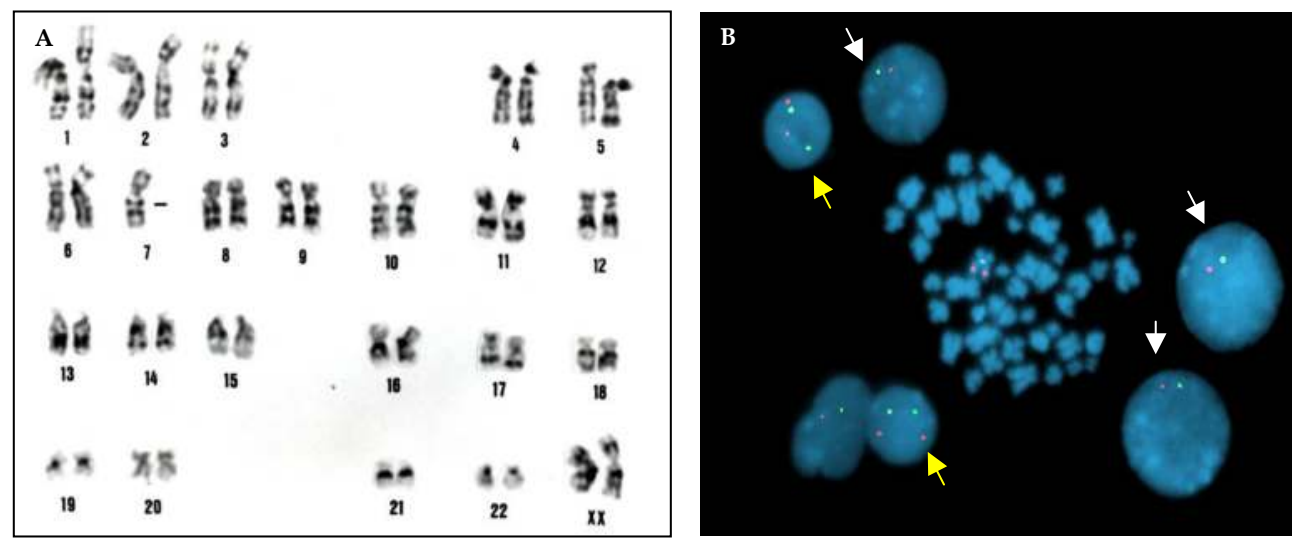

Fig. 4. (A) Karyotype of bone marrow cell by GTG-banding showing: Monosomy 7. (B) FISH analysis showing monosomy 7 using the probe: LSI D7S486 spectrum orange/ CEP 7 spectrum green, Vysis, Inc. Downers Grove, USA. It may be observed in the interphases nucleus four signals characterizing normal cells (yellow arrows) and others interphases nucleus showing two signals (white arrows), confirming the loss of the chromosome 7.

The molecular mechanisms involved in MDS mainly, in childhood, are not well defined. A recent molecular study of TP53 and c-fms genes showed no mutations in children with MDS. The presence of mutations in onocogene $N$-ras also occurs in a very low frequency in childhood MDS. However, mutations in TP53, c-fms and N-ras genes are involved in the development and evolution from MDS to AML in adult patients (Fernandez et al., 1998; Jekic et al., 2004, 2006). These results suggest that some molecular mechanisms involved in the pathogenesis of MDS in children are different from those seen in adults. It has been observed the importance of epigenetic alterations in the pathogenesis of MDS, but the majority of these studies is focused in adult patients. Few studies showed the epigenetic alterations in children (Hasegawa et al., 2005; Rodrigues et al., 2010; Vidal et al., 2007). Rodrigues and colleagues, 2010, suggested that methylation of $p 15^{I N K 4 B}$ and $p 16^{I N K 4 A}$ genes are epigenetic alterations in pediatric MDS patients and, as in adult patients, are later events associated with the leukemogenesis process in MDS.

\subsection{Cytogenetics and epigenetics alterations in myelodysplastic syndrome}

The discovery of non-random chromosomal abnormalities in primary MDS confirmed the clonality, providing a way to identify the malignant clone and point out some oncogenes 
and tumor suppressor genes possibility involved in the development and progression of disease. The cytogenetics evaluation of a bone marrow sample from patients with MDS has become an integral part of clinical care. The clonal cytogenetic alterations can be detected in $30-50 \%$ of adult patients with primary MDS. In pediatric patients this incidence is $50-70 \%$ of the cases. These changes range from a single numerical or structural changes to complex genomic lesions involving three or more different chromosomes. The most frequent chromosomal abnormalities in MDS are: $\operatorname{del}(5 q)$, $\operatorname{del}(7 q) /-7,+8, \operatorname{del}(11 q), \operatorname{del}(12 p), \operatorname{del}(17 p), \operatorname{del}(20 q)$ and loss of $Y$ chromosome (Bejar et al., 2011; Fernandez et al., 2000; Haase, 2008).

The frequency of cytogenetic abnormalities increases with the severity of disease as well as the risk of leukemic transformation. In this group, unfavorable chromosomal abnormalities are frequently found as complex abnormalities or karyotypes including monosomy 7 or trisomy 8 (Bacher, 2010; Fernandez et al., 2000). A normal karyotype is found in $30-60 \%$ of patients with MDS. This group of patients is almost certainly genetic heterogeneous, probably the leukemogenic alterations occurred at the molecular level and were not detectable with standard cytogenetic methods (Greenberg et al., 1997; Onley \& Le Beau, 2009).

In MDS, some studies suggest some genes involved with specific chromosome alterations, as the del(5q). The $5 q$ syndrome represents a distinct clinical entity characterized by a $\operatorname{del}(5 q)$ as the sole karyotypic abnormality. The $5 q$ syndrome occurs commonly in women. The initial laboratory findings are usually a macrocytic anemia with a normal or elevated count. The diagnosis is usually RA. On bone marrow examination, abnormalities in the megakaryocytic lineage (particularly micromegakaryocytes) are prominent. These patients have a favorable prognosis, with low rates of leukemic transformation and a relatively long survival of several years. The loss of a single copy of the RPS14 gene may be involved in the MDS 5q- pathogenesis. The RPS14 is an essential component of the 40S subunit of ribosomes and ribosomes synthesis is impaired in CD34 + cells from $5 q$ syndrome patients (Onley \& Le Beau, 2009).

The role of cytogenetic analysis in MDS is an important factor for establishing the diagnosis, prognosis and therapeutic plan and the follow up of altered clinical behavior of the disease. The chromosomal abnormalities have not only provided insights into prognosis but also into the molecular pathogenesis of this heterogeneous disease. The type of chromosomal abnormality (unbalanced, most commonly the result of the loss of a whole chromosome or a deletion of a part of a chromosome) in primary MDS indicates that the main class of genes involved in the pathogenesis of this disease is the tumor suppressor genes. The mechanism involved in the inactivating tumor suppressor genes are deletions, mutations and epigenetic alterations as the DNA methylation.

Three main epigenetic events regulate tumor-associated genes: 1) the aberrant hypermethylation of tumor suppressor genes, 2) post-translational modifications of histones and 3) post-transcriptional modifications by regulatory miRNA. The underlying causes of the pathogenesis of MDS remain to be fully elucidated. Knudson model of the "two hits" provides the basis of the concept of a multistep pathogenesis in the development of MDS, where loss or inactivation of only one allele is not sufficient to result in the development of tumors or expansion of a malignant clone. In fact, MDS in early stages with its relatively 
slow (but with increased tendency) to AML progression represents a prototype of the multistep concept in leukemogenesis with accumulation of cellular and molecular defects during the initiation and disease progression (Vigna et al., 2011).

Recent studies have revealed that DNA methylation and histone modification may be controlled by Polycomb-group (PcG) proteins, which may give new clues toward understanding the epigenetic mechanisms of MDS. PcG family members, such as EZH2, RING1 and BMI-1, are essential for the self-renewal and proliferation of normal cells. However, the induced over expression of these proteins can drive tumorigenesis. In MDS patients, the expression of EZH2, RING1 and BMI 1 were positively correlated with the IPSS prognostic scoring system, suggesting that the over expression of each of these three genes is a negative prognostic indicator ( $\mathrm{Xu}$ et al., 2011). The EZH2 expression level was positively correlated with a reduction of peripheral blood cells, which was likely to reflect the severity of ineffective hematopoiesis. Molecular analyses of EZH2 showed that deletions, missense and frameshift mutations strongly suggest that EZH2 is a tumor suppressor gene in MDS pathogenesis (Nikoloski et al., 2010). Other mutations have been identified in the genes that regulate endogenous methylation networks within cells including IDH1/2, TET2 and DNMT3. The relevance of these lesions in being able to predict response to epigenetic modulators and their correlation with epigenetic signatures in MDS are beginning to emerge (Tan \& Wei, 2011).

In MDS, aberrant silencing due to promoter hypermethylation involves genes encoding cell adhesion molecules, cell cycle regulation and tumor suppressor genes possibly leading to dysregulation of hematopoiesis. It has been shown in MDS a high prevalence of methylation for the tumor suppressor genes $p 15^{I N K 4 B}$, cadherin 1 (CDH1), death associated protein kinase (DAPK) and suppressor of cytokine signaling (SOCS-1). Some methylation patterns in specific genes in MDS can predict poor prognosis even in early stage of the disease (Aggerholm et al., 2006; Bejar et al., 2011; Vigna et al., 2011). Hence, epigenetic changes have been implicated as potential mechanisms in the pathogenesis and progression of MDS, which has already resulted in promising therapeutic approaches in a subset of patients.

\subsection{Methylation changes in myelodysplastic syndrome: Diagnostic and therapeutical implications}

Different studies in MDS showed the importance of methylation changes during the clinical evolution of disease to AML. So, the identification in the diagnosis of these alterations is important for risk group stratification. Aberrant DNA methylation is view as a poor prognostic feature in MDS. For example, p15 INK4B and p16 ${ }^{I N K 4 A}$ genes are members of cyclin dependent kinase inhibitors family which controls the progression of cell cycle from G1 to $S$ phase. The products of these genes regulate RB function by modulating the complexes of cyclin D-CDK4/6 which can phosphorylate and inactive the RB protein, and set up an important pathway for inhibiting cell growth (Serrano et al., 1996; Shimamoto et al., 2005). In addition, $\mathrm{p} 15^{I N K 4 B}$ has been suggested to act as a regulator of proliferation and differentiation in myelo-monocytic and megakaryocytic lineages by arresting the cell cycle (Sakashita et al., 2001; Teofili et al., 2000). Therefore, the silencing of these genes via aberrant methylation is a critical event in leukaemogenesis. In MDS, aberrant methylation of p15INK4B 
gene has been related to more aggressive subtypes of disease and it is a possible biomarker of disease evolution (Quesnel et al., 1998; Rodrigues et al., 2010).

Another gene methylated in MDS is the death-associated protein kinase (DAP-kinase), a proapoptotic serine/threonine kinase. The analysis of the methylation status of DAP-kinase in bone marrow samples from patients with MDS at the time of initial diagnosis showed that hypermethylation of DAP-kinase was significantly correlated to loss of DAP-kinase expression. Alteration in the apoptotic response due to the loss of DAP-kinase function may be an early event in the transformation pathway to secondary leukemia via myelodysplasia (Wu et al., 2011).

The mechanistic bases of CIMP (CpG island methylator phenotype) in MDS remains unknown. One proposed mechanisms involves aberrant recruitment of DNA methyltransferases to CpG islands and/or loss of methylation protection. Another possible explanation is that hypermethylation may not be directly linked to the methylation machinery, but rather reflects environmental exposures (Shen et al., 2010).

The reversible character of epigenetic alterations (in contrast to genetic changes) was an important point for the development of therapeutic strategies evolving various epigenetic components for anticancer therapy. So, in MDS, the characterization in the diagnosis of epigenetic biomarkers of disease evolution may indicate the use of hypomethylating drugs in this group of patients.

A large number of treatments has been used in adults and children with primary MDS, with the goal of eliminating the cytopenias as well as to recover hematopoiesis. One of the therapies used is the support that involves blood transfusions, antibiotics, growth factors alone or in combination, cyclosporin or anti-lymphocyte globulin (ATG) are also used in patients with hypocellular bone marrow. In more advanced MDS subtypes (RAEB, RAEB-t), in some cases, it has been used the chemotherapy. The allogeneic hematopoietic stem cell transplantation (HSCT) is the only curative therapeutic option for patients with MDS, however, its use is limited to patients up to 55 years old and patients who have histocompatible donors (Giralt et al., 2005; Kindwall-Keller \& Isola, 2009). For children with MDS, allogeneic HSCT is considered as the best treatment option (Niemeyer \& Kratz, 2008).

With the delineation of the characteristics that drive the biological phenotype of MDS, new drugs introduced in the treatment of this disease have shown a great therapeutic potential, such as the hypomethylant agents, called methyltransferase inhibitors (IMT). The representatives of this class include azacitidine (5-azacytidine) and decitabine (5-aza 2 'deoxycytidine). Both are incorporated into DNA and then irreversibly bind and inhibit the action of DNA methyltransferase. This interaction results initially in a semi-methylated DNA. However, after further cell cycles, it becomes completely unmethylated. The action of these drugs leads to reactivation of epigenetically repressed genes, such as tumor suppressor genes. Initial results showed that patients with higher-risk MDS have an increased time to AML transformation and an increase of survival time (Atallah et al., 2007; Fenaux et al., 2009; Silverman \& Mufti, 2005). The decitabine and azacytidine are approved for treatment of patients with int-2 and high-risk MDS. Demethylating agents seem to be the best choice for elderly patients with MDS, even in case of high risk cytogenetic changes in karyotype, like monosomy 7 (Gurion et al., 2010; Szmigielska-Kaplon \& Robak, 2011). 
Some studies have shown that reduced methylation overtime was correlated with better clinical response for patients during decitabine treatment. But, further studies of methylation dynamics, both before and after treatment, will be useful to determine the ability of epigenetic biomarkers to direct the treatment and may predict for the success (Shen et al., 2010). However, in some clinical trials, it was found that a number of patients does not respond to decitabine initially (primary resistance) and most patients, who initially respond to decitabine treatment, eventually relapse (secondary resistance) despite continued therapy. Clinical response to hypomethylating drugs in vivo is complex and may involve differentiation and immune activating components. Cytogenetic analysis showed that MDS patients after relapse using decitabine showed evolution in $20 \%$ patients with abnormalities such -7, del(16q) and +8 (Qin et al., 2011).

The understanding of the epigenetic changes characteristic of the malignant phenotype also permit the development of drugs that are able to target other regulators of chromatin conformation that contribute to aberrant gene transcription and dysregulated cell growth. The histone deacetylase inhibitors (HDAC) belong to one class of therapeutics developed using this paradigm. HDAC inhibitors modulate gene expression by inhibiting the deacetylation of histone lysine tails, relaxing the chromatin structure by decreasing the interaction between positively charged lysine tails of histones and negatively charged DNA. Although responses using HDAC inhibitors alone in MDS have been modest, preclinical data drives clinical trials in which they are utilized in combination with DNA methyltransferase inhibitors. Combination therapy offers the possibility of hematologic improvement and remission to MDS patients with previously untreatable disease (Vigna et al., 2011).

DNA methyltransferase inhibitors (hypomethylating agents) have emerged as options for the treatment of patients with MDS. These drugs lead to the progressive loss of methylation and reversal of gene silencing. In addition to their differentiation-inducing activity, these agents also have direct cytotoxic effects (Gurion et al., 2009). Currently available DNA methylation blocks all DNMTs. One of the main problems in using DNMT-Is in therapy is activation of cancer-promoting genes as well as other disease-promoting genes by hypomethylation. Recent studies suggest that there might be differences in the target specificity of different DNMTs. It is important to characterize the cancer related genes regulated by each of the DNMTs and develop DNMT gene-specific inhibitors. Moreover, treatment duration and maintenance therapy of using these agents require further investigation (Vigna et al., 2011).

\subsection{DNA methylation alterations as diagnostic and prognostic biomarkers}

Epigenetic transcriptional silencing of genes required for proliferation and differentiation of the hematopoetic cells are likely to contribute to the leukemogenic event underlying MDS. Altered DNA methylation patterns of some genes are not only of importance to our understanding of the molecular pathogenesis of the MDS, but may also serve as novel indicators for the diagnosis, the prognosis and the prediction of response to therapy. We can see in table 3 some genes that are methylated in MDS and are suggested as possible biomarkers that may aid the diagnosis and the prognosis. 


\begin{tabular}{|c|c|c|c|}
\hline Genes & Function & $\begin{array}{l}\text { MDS Incidence of } \\
\text { aberrant methylation }\end{array}$ & $\begin{array}{l}\text { Role in MDS } \\
\text { Pathogenesis / } \\
\text { Prognosis }\end{array}$ \\
\hline $\begin{array}{l}p 15^{I N K 4 B} \\
p 16^{I N K 4 A}\end{array}$ & $\begin{array}{l}\text { Members of the cyclin- } \\
\text { dependent kinase } \\
\text { (CDK) inhibitor family. } \\
\text { They play an } \\
\text { important pathway for } \\
\text { inhibiting cell growth. } \\
\text { Localization: 9p21 }\end{array}$ & $\begin{array}{l}\text { p15INK4 - adult } \\
\text { patients : } \\
61 \%(25 / 41) \text {; pediatric } \\
\text { patients: } \\
32 \%(15 / 47) ; \\
\text { p16INK4A - adult } \\
\text { patients : } 37 \%(15 / 41) \\
\text { pediatric patients: } 8 \% \\
(4 / 47)\end{array}$ & $\begin{array}{l}\text { High incidence in } \\
\text { RAEB and RAEB-t. } \\
\text { Hypermethylation in } \\
\text { both genes are } \\
\text { involved in evolution } \\
\text { from MDS to AML } \\
\text { and confers a poor } \\
\text { prognosis. } \\
\text { (Rodrigues et al., } \\
\text { 2010) }\end{array}$ \\
\hline $\begin{array}{l}\mathrm{CDH}-1 \\
\text { (E-cadherin) }\end{array}$ & $\begin{array}{l}\text { Homotypic cell-cell } \\
\text { adhesion protein, } \\
\text { involved in cell- } \\
\text { proliferation. } \\
\text { Localization: } 16 q 22 \\
\end{array}$ & $\begin{array}{l}\text { adult patients : } 39 \% \\
(16 / 41)\end{array}$ & $\begin{array}{l}\text { Occurs in the various } \\
\text { subgroups of MDS } \\
\text { with higher incidence } \\
\text { in RAEB and RAEB-t. } \\
\text { (Solomon et al., 2008) }\end{array}$ \\
\hline $\begin{array}{l}\text { SOCS-1 } \\
\text { (suppressor } \\
\text { of cytokine } \\
\text { sinaling) }\end{array}$ & $\begin{array}{l}\text { Member of stat- } \\
\text { induced STAT } \\
\text { inhibitor (SSI), also } \\
\text { known as a suppressor } \\
\text { of cytokine signaling } \\
\text { (SOCS) family. } \\
\text { Localization: } 16 \mathrm{p} 13\end{array}$ & $\begin{array}{l}\text { adult patients : } 31 \% \\
(27 / 86)\end{array}$ & $\begin{array}{l}\text { Higher risk of } \\
\text { leukemic } \\
\text { transformation. } \\
\text { (Brakensiek et al., } \\
\text { 2005) }\end{array}$ \\
\hline $\begin{array}{l}D A P K 1 \\
\text { (death } \\
\text { associated } \\
\text { protein } \\
\text { kinase) }\end{array}$ & $\begin{array}{l}\text { DAPK1 is a } \\
\text { serine/threonine } \\
\text { kinase, a positive } \\
\text { mediator of gamma- } \\
\text { interferon induced } \\
\text { programmed cell } \\
\text { death. Localization: } \\
\text { 9q34.1 }\end{array}$ & $\begin{array}{l}\text { adult patients : } 42,3 \% \\
(33 / 78)\end{array}$ & $\begin{array}{l}\text { Associated with } \\
\text { unfavorable } \\
\text { cytogenetic risk } \\
\text { group. Poor } \\
\text { prognosis. } \\
\text { (Xu et al., 2011) }\end{array}$ \\
\hline $\begin{array}{l}\text { FHIT } \\
\text { (fragile } \\
\text { histidine } \\
\text { triad) }\end{array}$ & $\begin{array}{l}\text { Fragile histidine triad } \\
\text { gene member of a } \\
\text { superfamily HIT of } \\
\text { nucleotide binding } \\
\text { proteins. Localization: } \\
\text { 3p14.2 }\end{array}$ & $\begin{array}{l}\text { adult patients : } 47,2 \% \\
(26 / 55)\end{array}$ & $\begin{array}{l}\text { Advanced stages of } \\
\text { MDS } \\
\text { (RAEB, RAEB-t). } \\
\text { Disease progression. } \\
\text { (Lin et al., 2008) }\end{array}$ \\
\hline $\begin{array}{l}\text { RIZ-1 } \\
\text { (retinoblasto } \\
\text { ma protein- } \\
\text { interacting } \\
\text { zinc finger } \\
\text { gene) }\end{array}$ & $\begin{array}{l}\text { Induce cell cycle arrest, } \\
\text { apoptosis. } \\
\text { Localization: 1p36 }\end{array}$ & $\begin{array}{l}\text { adult patients: } 50 \% \\
(17 / 34)\end{array}$ & $\begin{array}{l}\text { No statistically } \\
\text { differences in low and } \\
\text { high risk, it is } \\
\text { relatively early event } \\
\text { in MDS. } \\
\text { (Mori et al., 2011) }\end{array}$ \\
\hline
\end{tabular}

Table 3. Methylation alterations in genes involved in the pathogenesis of MDS. 


\section{Statistical analysis of epigenetics biomarkers}

Biomarkers have become important tools for diagnosis and treatment of a wide range of illnesses, including cancer. Early detection of cancer through biomarkers will allow for the development of new therapeutic procedures in order to increase survival rate of patients diagnosed with cancer. To help the evaluation of new biomarkers for medical practice, we use statistical methods. In this section, we shall discuss statistical techniques for biomarkers evaluation in the myelodysplastic syndrome (MDS). While the application of the methods presented is on biomarkers in MDS, the content of this section can be applied to any medical research.

The main mathematical concept necessary to understand statistical methods is probability. Although earlier work on the subject was done by the Italian mathematician Giralamo Cardano (1501-1576), the investigation of probability as a branch of Mathematics sprang about 1654 with two great French mathematicians: Blaise Pascal (1623-1662) and Pierre Fermat (1601-1665). Both Pascal and Fermat were interested in predicting outcomes in the games of chance popular among the French nobility of the mid-seventeenth century. Of course, we shall not do a discourse on probability. But we need to say that the theory of probability underlies the procedures in inferential statistics, which is very useful to medicine and other disciplines in the health field. In our exposition, we will try to avoid mathematical formulas and theorems.

\subsection{Descriptive statistics and inferential statistics}

Statistics is a branch of Mathematics. The word "statistics" derives from the Latin word status, meaning "manner of standing" or "position". Statistics were first used by tax assessors to collect information for determining assets and assessing taxes. Nowadays, the application of statistics is broad and includes business, marketing, economics, agriculture, education, medicine and others. Statistics applied to medicine and other health disciplines is called biostatistics or biometrics. For those who would like to review or study this subject we recommend the book of Zar, 2010.

Statistics is divided into two branches: descriptive and inferential. The goal of descriptive statistics is to organize and summarize data. And the goal of inferential statistics is to draw inferences and reach conclusions about a population, when only a sample from the population has been studied. A population is a complete set of observations, patients, measurements, and so forth. A sample is a subset of a certain population.

To organize data and summarize their main characteristics we can use tables, graphs and quantitative indices. Tables are often used to present qualitative and quantitative data. Graphs are used widely to provide a visual display data. The bar diagram, histogram and frequency polygon are three graphic formats that are commonly used to present medical data. A table or a graph in which all values of a variable of interest are displayed with their corresponding frequency is called a frequency distribution, or simply a distribution. We shall see in the next subsection that in inferential statistics we are interested in a special type of distribution: a probability distribution.

Quantitative indices are numbers that describe the center and the variation of a distribution. Quantitative indices that describe the center of a distribution are referred to as measures of 
central tendency. The mean, known also as the arithmetic mean, median and mode are three common measures of central tendency. Quantitative indices that describe the variation or dispersion of a distribution are referred to as measures of dispersion. The range, variance and standard deviation are three common measures of dispersion. In medicine we usually work with other quantitative indices as risk difference, relative risk and odds ratio. To draw inferences and reach conclusions about a population, when only a sample from that population has been studied, we need to know probability, because we use statistical hypothesis testing and estimates.

Statistical hypothesis tests can be parametric or nonparametric. Surveys of statistical methods used in journals indicate that the $t$ test is one of the most commonly used statistical tests. The percentages of articles that use the $t$ test range from $10 \%$ to more than $60 \%$. Williams and colleagues (1997) noted a number of problems in using the $t$ test. Welch and Gabbe (1996) found a number of errors in using the $t$ test when a nonparametric procedure is called for. Thus, being able to use these techniques needs some skills in order to choose the correct statistical test.

\subsection{Parametric and nonparametric tests}

Combining the notion of a frequency distribution (descriptive statistics) and probability, we can explain what means a probability distribution. A probability distribution is a table or a graph that describes the probability of an event occurs. It describes what probably will happen instead of describing what really happened.

A probability distribution can be discrete or continuous. An important example of a discrete probability distribution is the binomial distribution and an important example of a continuous distribution is the normal distribution.

The binomial distribution is generated from a series of Bernoulli trials, named in honor of James Bernoulli (1654-1705). The binomial distribution is used when we have only two possible outcomes, which are mutually exclusive. For example, survived/died, male/female, adequate/inadequate, and others.

The normal distribution is known also as the Gaussian distribution, in honor of Carl F. Gauss (1777-1855), who made significant contributions in the beginning of the 19th century to its development. The geometric representation of such a distribution is a symmetric and bell-shaped curve, known as the normal curve. The most important characteristic of the normal curve is the following: if perpendiculars are erected at the distance of one standard deviation above and one standard deviation below the mean, approximately $68 \%$ of the total area is between these perpendiculars, the $x$-axis and the curve. If perpendiculars are constructed at a distance of two standard deviations above and below the mean, approximately $95 \%$ of the total area is enclosed. If perpendiculars are set at a distance of three standard deviations to the left and right of the mean, approximately $99,7 \%$ of the total area is included, as shown in Figure 5. Since there is a correspondence between area and probability, we have information about the probability of data be located $\mathrm{k}$ standard deviation around the mean, for $\mathrm{k}=1,2$ or 3 .

Comparing the above information with the information obtained by the Chebyshev theorem, we note that we can obtain more accurate results when data present a normal 
distribution. The Chebyshev theorem claims that, for any probability distribution, the probability of data be located $k$ standard deviation around the mean is, at least, $1-1 / k^{2}$, where $\mathrm{k}$ is a positive number greater than 1 . Table 4 compares the Chebyshev's proportions with the proportions of a normal distribution, assuming $\mathrm{k}=1,2,3$ or 4 .

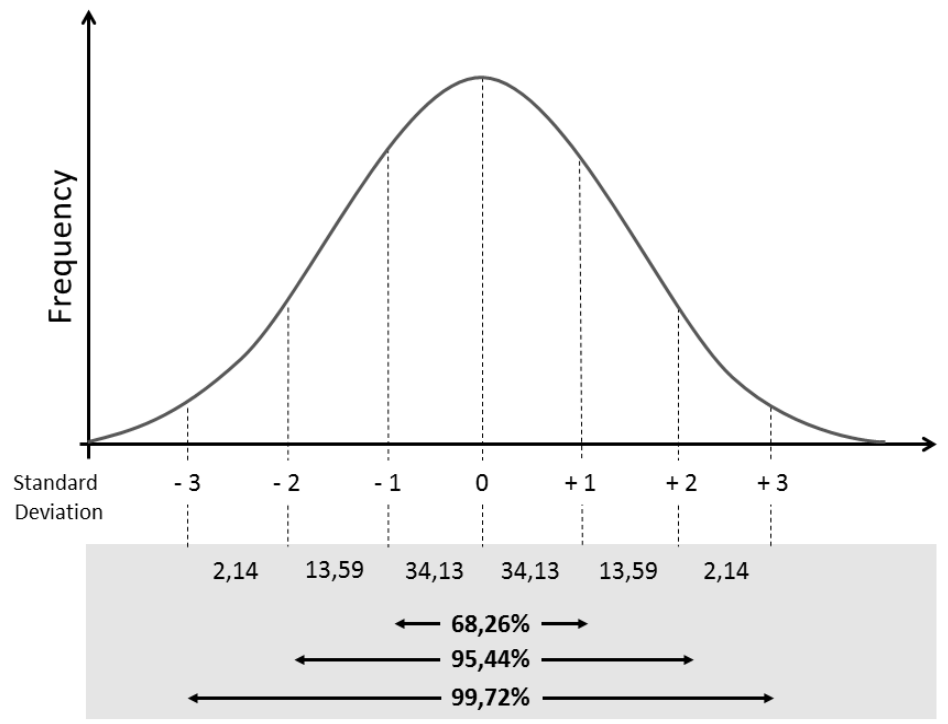

Fig. 5. Gaussian distribution.

\begin{tabular}{|c|c|c|}
\hline $\mathbf{k}$ & Any distribution & Normal distribution \\
\hline $\mathbf{1}$ & no information & $68 \%$ \\
\hline $\mathbf{2}$ & $\geq 75 \%$ & $95 \%$ \\
\hline $\mathbf{3}$ & $\geq 88 \%$ & $99,7 \%$ \\
\hline $\mathbf{4}$ & $\geq 93,75 \%$ & $99,9 \%$ \\
\hline
\end{tabular}

Table 4. Chebyshev' proportions compared with proportions of a normal distribution.

If we decide to approximate clinical measurements by a normal curve, we are deciding to use a parametric hyphotesis test. A hypothesis test asks if an effect (difference) exists or not using statistics tests to verify the hypothesis that there is no difference. This is the null hypothesis and designated $\mathrm{H}_{0}$. The hypothesis that contradicts $\mathrm{H}_{0}$ is the alternative hypothesis and written $\mathrm{H}_{\mathrm{A}}$. In the null hypothesis we use the words no difference or equal to and in the alternative hypothesis we use the words different from, less than or greater than. But let us mention that, in fact, we should say no statistical difference, statistically equal to, statistically different from, statistically less than or statistically greater than, because we are dealing with the probabilities of an event happens or not. When we retain $\mathrm{H}_{\mathrm{A}}$ (equivalently reject $\mathrm{H}_{0}$ ), we say the results are significant and when we retain $\mathrm{H}_{0}$ (equivalently reject $\mathrm{H}_{\mathrm{A}}$ ), we say the results are not significant. Because we are dealing with probabilities, this implies in making two possible errors from four possible relations between statistical conclusions and real situations, as shown in Table 5. 


\begin{tabular}{|c|c|c|c|}
\hline & \multicolumn{2}{|c|}{ Real difference } \\
\hline & & Presence & Absence \\
\hline \multirow{2}{*}{$\begin{array}{l}\text { Conclusion of the } \\
\text { statistical test }\end{array}$} & $\begin{array}{l}\text { Results are } \\
\text { significant }\end{array}$ & True & Type I error \\
\hline & $\begin{array}{l}\text { Results are not } \\
\text { significant }\end{array}$ & Type II error & True \\
\hline
\end{tabular}

Table 5. Relations between statistical conclusions and real situations.

The two errors mentioned in the previous paragraph are known as Type I error and Type II error. A Type I error leads to a false positive conclusion. The probability of such an error occurs is noted by $\mathbf{\alpha}$. Mathematically, $\mathbf{\alpha}$ is a conditional probability: $\mathbf{\alpha}$ is the probability of reject $\mathrm{H}_{0}$ when there is no real difference. A Type II error leads to a false negative conclusion. The probability of such an error occurs is noted by $\boldsymbol{\beta}$. Mathematically, $\boldsymbol{\beta}$ is a conditional probability: $\boldsymbol{\beta}$ is the probabilities of retain $\mathrm{H}_{0}$ when there is a real difference.

Statistical tests are used to estimate the probability of a Type I error. In the literature, we usually use $\boldsymbol{\alpha}<0.05$. This means we are assuming a probability less than 0.05 of rejecting $\mathrm{H}_{0}$ when there is no real difference between treatments, drugs or procedures. In other words, if the study were repeated one-hundred times, we probably would find five outcomes showing $\mathrm{H}_{0}$ should be accepted.

There are several tests commonly used in the medical literature; they are resumed in Table 6. Investigators should decide by using a parametric or a nonparametric test. This choice depends on the purpose of the study, the size of the sample, the type of the variables involved at the study, for instance. To use a parametric test we need to guarantee that the sampling distribution is normal or approximately normal. Because normal distribution has nice mathematical properties (bell-shaped, symmetric, and so on), using a parametric test leads to better statistical results compared with a nonparametric test. In other words, we say that nonparametric tests are less powerful, in the sense that they lead to a small probability to reject $\mathrm{H}_{0}$, when $\mathrm{H}_{0}$ is false.

\begin{tabular}{|l|c|c|}
\hline \multicolumn{3}{|c|}{ To test the statistical significance of the difference between ... } \\
\hline Two or more proportions & Chi-square & nonparametric \\
\hline Two proportions & Fisher's exact & parametric \\
\hline Two medians & Mann-Whitney & nonparametric \\
\hline Two means & t-Student & parametric \\
\hline More than two means & Kruskal-Wallis (one-factor) & nonparametric \\
\hline More than two means & ANOVA (one-factor) & parametric \\
\hline More than two means & ANOVA (more-factors) & parametric \\
\hline
\end{tabular}

Table 6. Statistical tests usually used in the medical literature.

When we use a statistic test we compute a $p$-value. The $p$-value is the probability of obtaining a result as extreme or more extreme than the sample value, assuming that the null hypothesis is true. The sample value is calculated. Depending on the test we use, there is a specific formula to calculate the sample value. Appropriate computer software can do such a calculation. 
An increasing number of journals require that investigators include p-values in their manuscripts. When p-values are given, we are able to compare this probability to our own decision rule, which is the value of $\boldsymbol{\alpha}$. If the p-value is less than $\boldsymbol{\alpha}$, we say that the results are significant statistically. If the $\mathrm{p}$-value is greater than $\mathbf{\alpha}$, we say that the results are not significant statistically.

\subsection{Statistical methods for evaluation of biomarkers in myelodysplastic syndrome}

Biostatistics gives us important tools to evaluate biomarkers in myelodysplastic syndrome and other diseases. Quantitative indices, estimates, hypothesis tests and survival tables are useful to point out biomarkers. We already discussed about quantitative indices and hypothesis tests. Let us make few comments about estimates and survival tables.

In many situations, populations are so large that it is impossible to describe their central tendency and dispersion by studying $100 \%$ of their members, or by studying a sufficiently large portion of population to justify treating sample statistics as population parameters. In other situations, clinicians may study a new phenomenon with little basis to determine a population parameter. In these cases, we use estimates. Two types of estimates of a population parameter can be used: a point estimate and an interval estimate. A point estimate is a single numerical value of a sample statistic used to estimate the corresponding population parameter. Point estimates are not used widely because the value of some statistic, such as the sample mean, varies from sample to sample. So, an interval estimative is typically used. An interval estimate is a range of values which the parameter is likely to occur. Interval estimates are also called confidence intervals.

Survival tables are used to describe prognosis. Prognosis is a prediction of the future course of a disease following its onset (Fletcher et al., 1988). We can describe the prognosis of a disease considering a fixed period of time (measures or taxes) or considering varying periods of time (survival tables). Table 7 shows the common measures used to describe prognosis when we consider a fixed period of time.

\begin{tabular}{|l|l|}
\hline \multicolumn{1}{|c|}{ Measure } & \multicolumn{1}{c|}{ Definition } \\
\hline Five-year survival & $\begin{array}{l}\text { Percentage of patients who survive for five years from a certain } \\
\text { time of the course of the disease }\end{array}$ \\
\hline Response & $\begin{array}{l}\text { Percentage of patients who show some evidence of improvement } \\
\text { after a procedure or an intervention }\end{array}$ \\
\hline Remission & $\begin{array}{l}\text { Percentage of patients who start a period in which the disease is } \\
\text { not detectable }\end{array}$ \\
\hline Recurrence & $\begin{array}{l}\text { Percentage of patients who present reappearance of the disease } \\
\text { after a free period }\end{array}$ \\
\hline
\end{tabular}

Table 7. Common measures that describe prognosis.

Survival tables can handle situations in which patients enter in some trial at different times and are followed for varying periods. We usually consider the length of time in a certain trial as being days, weeks or months and the end point may be, in the MDS case, death or the reappearance of the disease. The usual method used to construct a survival table is the Kaplan-Meier method. The curve obtained from the data presented in a survival table is called a survival curve. 
The survival tables can allow us to compare two or more groups of patients. In this case, the first thing we should do is draw the survival curves for the two (or more) groups on the same graph. Statistical methods are important here, because we cannot make judgments simply on the basis of the amount of separation between the curves; a small difference may be statistically significant if the sample size is large, and a large difference may not if the sample size is small. We have mainly two methods to determine if the differences are statistically significant: the Wilcoxon rank sum test and the log rank test. Figure 6 shows comparative survival curves for pediatric and adult patients diagnosed with MDS treated with allogeneic hematopoietic stem cell transplantation (HSCT).

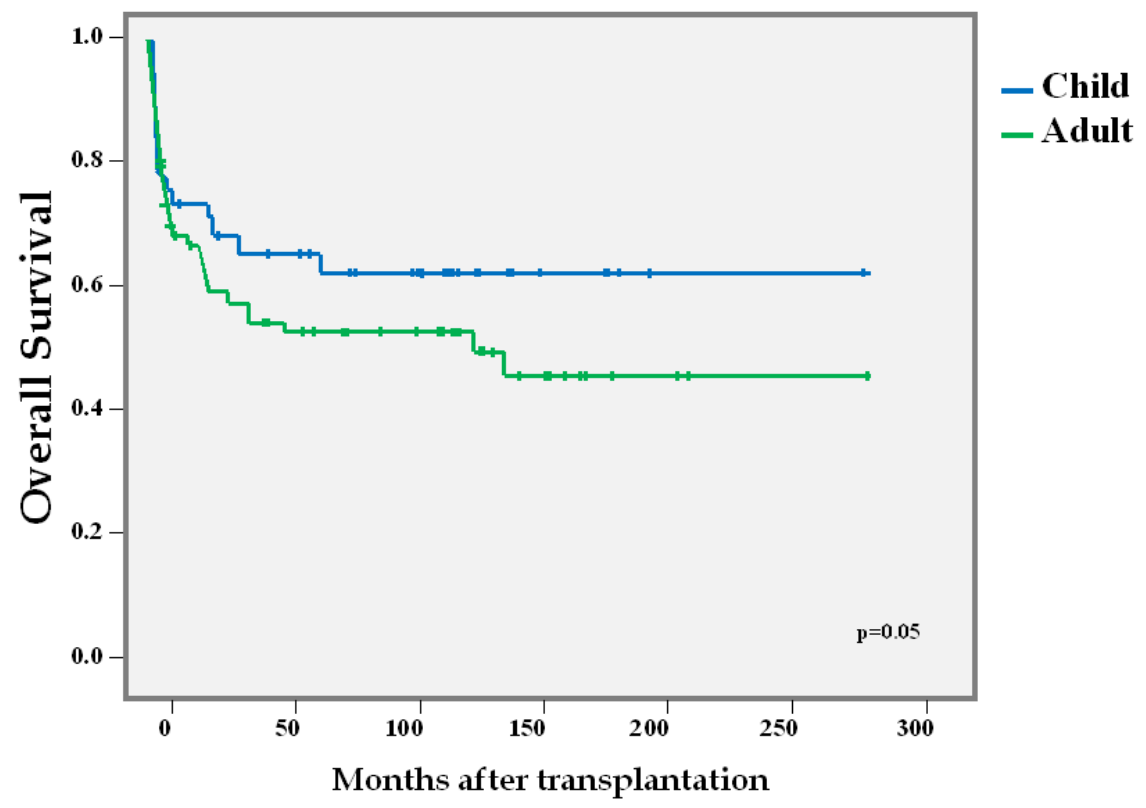

Fig. 6. Overall survival of primary MDS patients treated with allogeneic HSCT, pediatric patients versus adult patients.

In the Rodrigues et al (2010) study, the authors studied the methylation status of the p15INK4B and p16 INK4A genes in 47 pediatric patients with MDS, its correlation with subtype, and the role of p15 INK4B and p16INK4A in the evolution of MDS toward AML. The results obtained suggest that methylation of these genes is an epigenetic biomarker of pediatric disease evolution. The authors used some statistical tools presented here. For example, the correlation between $\mathrm{p} 15^{\mathrm{INK} 4 \mathrm{~B}}$ gene methylation status and subtypes of pediatric primary MDS, considering initial stage RC, and later stages RAEB and RAEB-t, was assessed by the chi-square test, which is a nonparametric test. The statistical analysis suggested that the frequency of p15 INK4B gene methylation was significantly higher in later stages of disease compared with the initial stage, with $\mathrm{p}$-value $<0.003$. The correlation between p16 $6^{\mathrm{INK}} 4 \mathrm{~A}$ gene methylation status and subtypes of pediatric primary MDS was also assessed by the chisquare test, with a slight modification. In fact, it is a correction factor, which is necessary when we have a small number of data. This is known as chi-square with continuity 
correction or chi-square with Yates'correction. The results obtained suggested that the frequency of p16INK4A gene methylation was found more frequently in subtypes characterizing the advanced stages of MDS, with $\mathrm{p}$-value $<0.05$.

Quantitative analysis to evaluate whether there was a correlation between percentage of p15INK4B methylation and MDS subtypes was performed in (Rodrigues et al., 2010). The percentage of p15INK4B methylation was higher in RAEB and RAEB-t compared to RC. The authors used ANOVA (one-factor) and obtained a p-value $<0,0001$. The same result was obtained for the p16INK4A gene. The authors used ANOVA (more-factors) to verify that QMS-PCR method was more sensitive than COBRA method, obtaining a p-value $<0.0001$, although both methods were accurate in showing a correlation between the subtypes of disease and the level of methylation.

The Mann-Whitney test was also used. The authors calculated the mean time of disease evolution in patients who had p15 INK4B methylation and in patients with no p15 INK4B methylation. The results were 4.6 months and 14.6 months, respectively. The mean time of disease evolution for patients who had p15INK4B methylation, therefore, was three times less than the mean time of evolution for patients who had no p15 ${ }^{\mathrm{INK}} 4 \mathrm{~B}$ methylation, which was statistically significant by using Mann-Whitney ( $\mathrm{p}$-value < 0.02).

Many concepts and theorems that are not familiar to medical professionals are used in Statistics, as null hypothesis, regression, parametric tests, the central limit theorem, Bayes theorem and so on. Of course, medical professionals should put away the complexity of such concepts and the mathematics is behind all this theory, although only mathematics could explain rigorously why these techniques really work. Nevertheless we must say that Statistics is an important tool that can help making decisions and must be used if the statistics outcomes are clinically meaningful. Accumulated experience and specific knowledge must be combined with results from statistical tests to assess the usefulness of a particular outcome or medical decision.

\section{Conclusion}

The field of cancer epigenetics is evolving rapidly. Advances in the understanding of chromatin structure, histone modifications, DNA methylation and transcriptional activity have resulted in an increasingly integrated view of epigenetics. These discoveries lead to the development of new treatments in cancer using epigenetic therapies. The MDS comprises a complex spectrum of hematopoietic stem cell disorders, where the study of epigenetics has brought new knowledge about the development and evolution of this disease to AML. Other important points in epigenetics studies in MDS were the introduction of the treatments using hypomethylant drugs and histone deacethylases inhibitors. The MDS may be considered a good model to study the epigenetics in the cancer pathogenesis research and the applicability in clinical. The identification of biomarkers of diagnosis and prognosis in MDS will possibility the elaboration of new classification and score prognostic systems and will help to understand the different pathways involved in the MDS pathogenesis. With the advance of the technologies involving epigenome projects, future research in the epigenetic therapies will be the development of inhibitors with specificity to particular biomarkers. 


\section{Acknowledgments}

This work was supported by grants from Rio de Janeiro State Research Support Foundation (FAPERJ) (project $\mathrm{n}^{\circ}$ E-26/102.235/2009), Brazil; Brazilian Ministry of Health, National Cancer Institute (INCA).

\section{References}

Agalioti, T.; Chen, G. \& Thanos, D. (2002). Deciphering the transcriptional histone acetylation code for a human gene. Cell, vol.111, pp. 381-392.

Aggerholm, A.; Holm, M.S.; Gulberg, P.; Olesen, L.H. \& Hokland, P. (2006). Promoter hypermethylation of p15Ink4B, HIC1, CDH1 and ER is frequent in myelodysplastic syndrome and predicts poor prognosis in early-stage patients. Eur J Haematol, vol.76, pp.23-32.

Akatas, D. \& Tuncbilek, E. (2006). Myelodysplastic syndrome associated with monosomy 7 in chuildhood: a retrospective study. Cancer Genets and Cytogen, vol.171, pp.72-75.

Atalhah, E.; Kantarjian, H. \& Garcia Manero G. (2007). The role of decitabine in the treatment of myelodysplastic syndromes. Exp O. Pharmac, vol.8, pp.65-73.

Bacher, U.; Haferlach, C.; Krogher, N.; Schnittger, S.; Kern, W.; Wiedemann, B.; Zander, A.R. \& Haferlach, T. (2010). Diagnostic tools in the indicators for allogeneic stem cell tranplantation in myelodysplastic syndromes. Biol Blood Marrow Transplant, vol.16, pp.1-11.

Bantignies, F. \& Cavalli, G. (2006). Cellular memory and dynamic regulation of polycomb group proteins. Curr Opin Cell Biol, vol.18, pp.275-283.

Bejar, R.; Levine, R. \& Ebert, B.L. (2011). Unraveling the molecular Pathophysiology of Myelodysplastic Syndrome. Journal of Clinical Oncology, vol.29, pp.504-515.

Bennett, J. \& Orazi, A. (2009). Diagnostic criteria to distinguish hypocellular acute leukemia from hypocellular myelodysplastic syndrome and aplastic anemia: recomendations for standardized approach. Haematologica, vol.94, pp.264-268.

Bennett, J.M.; Catovsky, D.; Daniel, M.T.; Flandrin, G.; Galton, D.A.; Gralnick, H.R. \& Sultan, C. (1982). Proposals for the classification of the myelodysplastic syndromes. British Journal of Haematology, vol.51, pp.189-199.

Brakensiek, K.; Länger, F.; Schlegelberger, B.; Kreipe, H. \& Lehmann, U. (2005). Hypermethylation of the suppressor of cytokine signalling-1 (SOCS-1) in myelodysplastic syndrome. Br J Haematol, vol.130, pp.209-17.

Brunning, R.D.; Orazi, A.; Germing, U.; Le Beau, M.M., Porwit, A.; Baumann, I.; Vardimann, J.W. \& Hellstrom-Lindberg, E. (2008). Myelodysplastic syndromes. In: Swedlow, S.H.; Campo, E.; Harris, N. L. ed. WHO classification of Tumors of Haematopoietic and Lymphoid Tissues. $4^{\text {th }}$ ed. Lyon, France: IARC Press; pp:88-107.

Davids, M.S. \& Steensma, D.P. (2010). The molecular pathogenesis of myelodysplastic syndromes. Cancer Biology \& Therapy, vol.10, pp.309-319.

Elghetany, M.T. (2007). Myelodysplastic Syndromes in Children: A Critical Review of Issues in the Diagnosis and Classification of 887 Cases from 13 Published Series. Arch Pathol Lab Med, vol.131, pp.1110-1116.

Ellis, L.; Atadja, P.W. \& Johnstone, R.W. (2009). Epigenetics in cancer. Targeting chromatin modifications. Mol Cancer Ther, vol.8, pp.1409-1420. 
Esteller, M. (2011). Cancer Epigenetics for the 21 ${ }^{\text {st }}$ Century: What's Next? Genes Cancer, vol.2, pp.604-606.

Fenaux,P.; Mufti, G.J., Hellstrom-Lindberg, E.; Santini, V.; Finelli, C.; Giagounidis, A.; Schoch, R.; Gatterman, N.; Sanz, G.; List, A.; Gore, S.D.; Seymour, JF.; Bennett, J.M.; Byrd, J.; Backstrom, J.; Zimmerman, L.; McKenzle, D.; Beach, C.; Silverman, L.R. (2009). Efficacy of azacitidine compared with that of conventional care regimens in the treatment of higher risk myelodysplastic syndromes: a randomized, open-label, phase III study. Lancet Oncol, vol. 10, pp.223-232.

Fernandez, T.S.; Ornellas, M.H.; Carvalho, L.O.; Tabak, D. \& Abdelhay, E. (2000). Chromosomal alterations associated with evolution from myelodysplastic syndrome to acute myeloid leukemia. Leuk Res, vol.24, pp.839-848.

Fernandez, T.S.; Souza, J.; Silva, M.L.; Tabak, D. \& Abdelhay, E. (1998). Correlation of N-ras point mutation with specific chromosomal abnormalities in primary myelodysplastic syndrome. Leuk Res, vol.22, pp.225-134.

Fletcher, R.; Fletcher, S. \& Wagner, E. (1988). Clinical Epidemiology: The Essentials. 2nd (Ed.). In: Williams \& Wilkins.

Garcia-Manero, G. (2010). Prognosis of Myelodysplastic Syndromes. Hematology Am Soc Hematol Educ Program, pp.330-337.

Giralt, S. (2005). Bone marrow transplant in myelodysplastic syndromes: new technologies, same questions. Curr hematol Rep, vol.4, pp.200-207.

Graham, J.S.; Kaye, S.B. \& Brown, R. (2009). The promises and pitfalls of epigenetic therapies in solid tumours. Eur J Cancer, vol.45, No.7, pp.1129-36.

Greenberg, P.; Cox, C.; Le Beau, M.M.; Fenaux, P.; Morel, P.; Sanz, G.; Sanz, M.; Vallespi, T.; Hamblin, T.; Oscier, D.; Ohyashiki, K.; Toyama, K.; Aul, C.; Mufti, G. \& Bennett, J. (1997). International Scoring System for Evaluating Prognosis in Myelodysplastic Syndromes. Blood, vol.89, pp.2079-2088.

Gurion, R.; Vidal, L.; Gafter-Gvili, A.; Belnik, Y.; Yeshurun, M.; Raanani, P. \& Shpilberg, O. (2010). 5-azacitidine prolongs overall survival in patients with myelodysplastic syndrome- a systematic review and meta-anlaysis. Haematologica, vol. 95, pp.3033010 .

Haase, D. (2008). Cytogenetics features in myelodysplastic syndromes. Annals of Hematology, vol.87, pp.515-526.

Haase, D.; Germing, U.; Schanz, J.; Pfeilstöcker, M.; Nösslinger, T.; Hildebrandt, B.; Kundgen, A.; Lübbert, M.; Kunzmann, R.; Giagounidis, A.A.; Aul, C.; Trümper, L.; Krieger, O.; Stauder, R.; Müller, T.H.; Wimazal, F.; Valent, P.; Fonatsch, C. \& Steidl, C. (2007). New insights into the prognostic impact of the karyotype in MDS and correlation with subtypes: evidence from a core dataset of 2124 patients. Blood, vol.110, pp.4385-4395.

Harris, N.L.; Jaffe, E.S.; Diebold, J.; Flandrin, G.; Muller-Hermelink, H.K.; Vardiman, J.; Lister, T.A. \& Bloomfield, C.D. (2000). The World Health Organization classification of hematological malignancies report of the Clinical Advisory Committee Meeting, Airlie House, Virginia. Mod Pathol, vol.13, pp.193-207.

Hasegawa, D.; Manabe, A.; Kubota, T.; Kawasaki, H.; Hirose, I.; Ohtsuka, Y.; Tsuruta, T.; Ebihara, Y.; Goto, Y.; Zhao, X.Y.; Sakashita, K.; Koike, K.; Isomura, M.; Kojima, S.; Hoshika, A.; Tsuji, K. \& Nakahata, T. (2005). Methylation status of p15 and p16 
genes inpediatric myelodysplastic síndrome and juvenile myelomonocytic leukemia. Br J Haematol, vol.128, pp. 805-812.

Hasle, H.; Baumann, I.; Bergsträsser, E.; Fenu, S.; Fischer, A.; Kardos, G.; Kerndrup, G.; Locatelli, F.; Rogge, T.; Schultz, K.R.; Starý, J.; Trebo, M.; van den Heuvel-Eibrink, M.M.; Harbott, J.; Nöllke, P. \& Niemeyer, C.M. (2004). The international prognostic scoring system (IPSS) for childhood myelodysplastic syndrome (MDS) and juvenile myelomonocytic leukemia (JMML). Leukemia, vol.18, pp.2008-2014.

Hasle, H. \& Niemeyer, C.M. (2002). Myelodysplastic syndrome and Juvenile Myelomonocytic leukemia in children. In: The Myelodysplastic syndromes: Pathobiology and Clinical Management. (Ed.) Bennett JM \& Dekker, Inc, Ney York, Basel, pp.299-344.

Hasle,H. \& Niemeyer, C. (2011). Advances in the prognostication and management of advanced MDS in children. Br J Haematol, vol. 154, pp.185-195.

Hasle, H.; Niemeyer, C.M.; Chessels, J.M.; Baumann, I.; Bennett, J.M.; Kerndrup, G. \& Head, D.R. (2003). A pediatric approach to the WHO classification of myelodysplastic and myeloproliferative diseases. Leukemia, vol.17, pp.277-282.

Hebeda, K.M. \& Fend, F. (2009). Changed concepts and definitions of myeloproliferative neoplasms (MPM), myelodysplastic syndromes (MDS) and myelodysplastic/myeloproliferative neoplasms (MDS/MPM) in the updated 2008 WHO classification. J Hematopathol, vol.2, pp.205-210.

Henrique, R. \& Jerônimo, C. (2004). Molecular detection of prostate cancer: a role for GSTP1 hypermethylation. Eur Urol, vol.46, No.5, pp.660-669.

Hrebackova, J.; Hrabeta, J. \& Eckschlager, T. (2010). Valproic acid in the complex therapy of malignant tumors. Curr Drug Targets, vol.11, No.3, pp.361-379.

Ingham, P.W. (1985). A clonal analysis of the requirement for the trithorax gene in the diversification of segments in Drosophila. J Embryol Exp Morphol, vol.89, pp.349365.

Jädersten, M. \& Hellström-Lindberg, E. (2008). Myelodysplastic syndromes: biology and treatment. Journal of Internal Medicine, vol.265, pp.307-328.

Jekic, B.; Novakovic, I.; Lukovic, L.; Kuzmanovic, M.; Popovic, B.; Pastar, I.; Milasin, J.; Bunjevacki, G. \& Bunjevacki, V. (2004). Low frequency of N-ras and K-ras gene mutations. Cancer Genet Cytogenet, vol.154, No.2, pp.180-182.

Jekic, B.; Novakovic, I.; Lukovic, L.; Kuzmanovic, M.; Popovic, B.; Milasin, J.; Bunjevacki, G.; Damnjanovic, T.; Cvjeticanin, S. \& Bunjevacki V. (2006). Lack of TP53 and FMS gene mutations in children with myelodysplastic syndrome. Cancer Genet Cytogenet, vol.166, No.2, pp.163-165.

Jerónimo, C.; Bastian, P.J.; Bjartell, A.; Carbone, G.M.; Catto, J.W.; Clark, S.J.; Henrique, R.; Nelson, W.G. \& Shariat, S.F. (2011). Epigenetics in prostate cancer: biologic and clinical relevance. Eur Urol, vol.60. No.4, pp.753-766.

Katz, V. J. (1993). A History of Mathematics, In: An Introduction. Harper Collins College Publishers, New York.

Kelly, T.K.; De Carvalho, D.D. \& Jones, P.A. (2010). Epigenetic modifications as therapeutic targets. Nat Biotechnol, vol.28, No.10, pp.1069-1078.

Kindwall-Keller, T. \& Isola, L.M. (2009). The evolution of hematopoietic SCT in myelodysplastic syndrome. Bone Marrow Transplantation, vol.43, pp.597-609. 
Kleff, S.; Andrulis, E.D.; Anderson, C.W. \& Sternglanz, R. (1995). Identification of a gene encoding a yeast histone H4 acetyltransferase. Journal of Biological Chemistry, vol.270, No.42, pp.24674-24677.

Levine, S.S.; King, I.F. \& Kingston, R.E. (2004). Division of labor in polycomb group repression. Trends Biochem Sci, vol.29, pp.478-485.

Lewis, E.B. (1978). A gene complex controlling segmentation in Drosophila. Nature, vol.276, No.5688, pp.565-570.

Lin, J.; Yao, D.M.; Qian, J.; Wang, Y.L.; Han, L.X.; Jiang, Y.W.; Fei, X.; Cen, J.N. \& Chen, Z.X. (2008). Methylation status of fragile histidine triad (FHIT) gene and its clinical impact on prognosis of patients with myelodysplastic syndrome. Leuk Res, vol.32, pp.541-1545.

Malcovati, L. \& Nimer, S.D. (2008). Myelodysplastic Syndromes: diagnosis and staging. Cancer Control, vol.15, pp.4-13.

Margueron, R. \& Reinberg, D. (2005). The Polycomb complex PRC2 and its mark in life. Nature, vol.2011, pp.343-349.

Marks, P.A. \& Dokmanovic, M. (2005). Histone deacetylase inhibitors: discovery and development as anticancer agents. Expert Opin Investig Drugs, vol.14, pp.1497-1511.

Mori, N.; Yoshinaga, K.; Tomita, K.; Ohwashi, M.; Kondoh, T.; Shimura, H.; Wang, Y.H.; Shiseki, M.; Okada, M. \& Motoji, T. (2011). Aberrant methylation of the RIZ gene in myelodysplastic syndrome and acute myeloid leukemia. Leuk Res, vol.35, No.4, pp.516-21.

Niemeyer, C.M. \& Baumann, I. (2008). Myelodysplastic Syndrome in Children and Adolescents. Semin Hematol, vol.45, pp.60-70.

Niemeyer, C.M. \& Kratz, C.P. (2008). Pediatric myelodysplastic syndromes and juvenile myelomonocytic leukemia: molecular classification and treatment options. $\mathrm{Br} \mathrm{J}$ haematol, vol.140, pp.610-624.

Nikoloski, G.; Langemeijer, S.M.; Kuiper, R.; Knops, R.; Massop, M.; Tönnissen, E.R.; van der Heijden, A.; Scheele, T.N.; Vandenberghe, P.; de Witte, T.; van der Reijden, B.A. \& Jansen, J.H. (2010). Somatic mutations of the histone methyltransferase gene EZH2 in myelodysplastic syndromes. Nat Genet, vol.42, No.8, pp.665-667.

Nishino, H.T. \& Cahng, C.C. (2005). Myelodysplastic syndromes: Clinicopathologic features, pathobiology and molecular pathogenesis. Arch Pathol Lab Med, vol. 129, pp.12991310.

Oliva, E.M.; Cuzzola, M.; Nobile, F.; Ronco, F.; D’Errigo, M.G.; Lagana, C.; Morabito, F.; Galimberti, S.; Cortelezzi, A.; Aloe Spiriti, M.A.; Specchia, G.; Poloni, A.; Breccia, M.; Ghio, R.; Finelli, C.; Iacopino, P.; Alimena, G. \& Latagliata, R. (2010). Changes in RPS14 expression levels during lenalidomide treatment in low and intermediate1 risk myelodysplastic syndromes with chromosome 5q deletion. Eur J Haematol, vol.85, No.3, pp.231-235.

Olney, H.J. \& Le Beau, M.M. (2009). The Cytogenetics and Molecular Biology of the Myelodysplastic Syndromes. In: Myelodysplastic Syndromes: Pathobiology and Clinical Management . (Ed.) 2nd Edition.,pp. 49-86.

Onley, H.J. \& Le Beau, M.M. (2009). Myelodysplastic Syndromes. In: Cancer Cytogenetics. (Ed.) Heim S and Mitelman F. ed. Wiley-Blackwell, pp.141-178.

Parker, J.E.; Mufti, G.J.; Rasoll, F.; Mijovic, A.; Devereux, S. \& Pagliuca, A. (2000). The role of apoptosis, proliferation, and the Bcl-2-related proteins in the myelodysplastic 
syndromes and acute myeloid leukemia secondary to MDS. Blood, vol. 96, pp.39323938.

Polychronopoulou, S.; Panagiotou, J.P.; Kossiva, L.; Mavrou, A.; Anagnostou, D. \& Haidas, S. (2004). Clinical and morphological features of pediatric myelodysplastic syndromes: a review of 34 cases. Acta pediatric, vol.93, pp.1015-1023.

Qin, T.; Castoro, R.; El Ahdab, S.; Jelinek, J.; Wang, X.; Si, J.; Shu, J.; He, R.; Zhang, N.; Chung, W.; Kantarjian, H.M.\& Issa, J.P. (2011). Mechanisms of Resistance to Decitabine in the Myelodysplastic Syndrome. PloS One, vol.6, pp.1-10.

Quesnel, B.; Guillerm, G.; Vereecque, R.; Wattel, E.; Preudhomme, C.; Bauters, F.; Vanrumbeke, M. \& Fenaux, P. (1998). Methylation of the p15(INK4b) gene in myelodysplastic syndromes is frequent and acquired during disease progression. Blood, vol.91, No.8, pp.2985-90.

Rajasekhar, V.K. \& Begemann, M. (2007). Concise review: roles of polycomb group proteins in development and disease: a stem cell prospective. Stem Cells, vol.25, pp.24982510.

Rao, P.M.; Antony, A.; Rajalakshmi, S. \& Sarma, D.S. (1989). Studies on hypomethylation of liver DNA during early stages of chemical carcinogenesis in rat liver. Carcinogenesis, vol.10, pp.933-37.

Razak, A.R.; Hotte, S.J.; Siu, L.L.; Chen, E.X.; Hirte, H.W.; Powers, J.; Walsh, W.; Stayner, L.A.; Laughlin, A.; Novotny-Diermayr, V.; Zhu, J. \& Eisenhauer, E.A. (2011). Phase I clinical, pharmacokinetic and pharmacodynamic study of SB939, an oral histone deacetylase (HDAC) inhibitor, in patients with advanced solid tumours. $\mathrm{Br} J$ Cancer, vol.104, No.5, pp.756-762.

Robertson, K.D.; Uzvolgyi, E.; Liang, G.; Talmadge, C.; Sumegi, J.; Gonzales, F.A. \& Jones, P.A. (1999). The human DNA methyltransferases (DNMTs) 1, 3a and 3b: coordinate mRNA expression in normal tissues and overexpression in tumors. Nucleic Acids Res, vol.27, No.11, pp.2291-2298.

Rodrigues, E.F.; Santos-Rebouças, C.B.; Pimentel, M.M.G.; Mencalha, A.L.; Dobbin, J.; Costa, E.S.; Fernandez, C.S.; Bouzas, L.F.; Abdelhay, E. \& Fernandez, T.S. (2010). Epigenetic alterations of $\mathrm{p} 15^{\text {Ink } 4 \mathrm{~B}}$ and $\mathrm{p} 16^{\text {Ink4A }}$ genes in pediatric primary myelodysplastic syndrome. Leukemia \& Lymphoma, vol.51, pp.1887-94.

Sakashita, K.; Koike, K.; Kinoshita, T.; Shiohara, M.; Kamijo, T.; Taniguchi, S. \& Kubota, T. (2001). Dynamic DNA methylation change in the CpG island region of p15 during human myeloid development. J Clin Invest, vol.108, No.8, pp.1195-1204.

Sasaki, H.; Manabe, A.; Kojima, S.; Tsuchida, M.; Hayashi, Y.; Ikuta, K.; Okamura, I.; Koike, K.; Ohara, A.; Ishii, E.; Komada, Y.; Hibi, S. \& Nakahata, T. (2001). MDS Committee of the Japanese Society of Pediatric Hematology, Japan. Myelodysplastic syndrome in childhood: a retrospective study of 189 patients in Japan. Leukemia, vol.15, No.11, pp.1713-1720.

Serrano, M.; Lee, H.; Chin, L.; Cordon-Cardo, C.; Beach, D. \& DePinho, R.A. (1996). Role of the Ink4a locus in tumor suppression and cell mortality. Cell, vol.85, pp.27-37.

Shen, L.; Kantarjian, H.; Guo, Y.; Lin, E.; Shan, J.; Huang, X.; Berry, D.; Ahmed, S.; Zhu, W.; Pierce, S.; Kondo, Y.; Oki, Y.; Jelinek, J.; Saba, H.; Estey, E. \& Issa, J.P. (2010). DNA methylation predicts survival and response to therapy in patients with myelodysplastic syndromes. J Clin Oncol, vol.28, No.4, pp.605-613. 
Shimamoto, T.; Ohyashiki, J.H. \& Ohyashiki, K. (2005). Methylation of p15Ink4B and Ecaherin genes is independently correlated with poor prognosis in acute myeloid leukemia. Leuk Res, vol.29, pp.653-659.

Silverman, L.R. \& Mufti, G. (2005). Methylation inhibitor therapy in the treatment of myelodysplastic syndrome. Nat Clin Pract Oncol, vol.2, pp.12-23.

Solé, F.; Espinet, B.; Sanz, G.F.; Cervera, J.; Calasanz, M.J.; Luño, E.; Prieto, F.; Granada, I.; Hernández, J.M.; Cigudosa, J.C.; Diez, J.L.; Bureo, E.; Marqués, M.L.; Arranz, E.; Ríos, R.; Martínez-Climent, J.A.; Vallespí, T.; Florensa, L. \& Woessner, S. (2000). Incidence, characterization and prognostic significance of chromosomal abnormalities in 640 patients with primary myelodysplastic syndromes. Grupo Cooperativo Español de Citogenética Hematológica. Br J Haematol, vol.108, No.2, pp.346-356.

Solé, F.; Luno, E.; Sanzo, C.; Espinet, B.; Sanz, G.F.; Cervera, J.; Calasanz, M.J.; Cigudosa, J.C.; Milla, F.; Ribera, J.M.; Bureo, E.; Marquez, M.L.; Arranz, E. \& Florensa, L. (2005). Identification of novel cytogenetic markers with prognostic significance in a series of 968 patients with primary myelodysplastic syndromes. Haematologica, vol.90, pp.1168-1178.

Solomon, P.R.; Munirajan, A.K.; Tsuchida, N.; Muthukumarasamy, K.; Rathinavel, A.; Selvam, G.S. \& Shanmugam, G. (2008). Promoter hypermethylation analysis in myelodysplastic syndromes: diagnostic \& prognostic implication. Indian J Med Res, pp.127:52-7.

Stresemann, C. \& Lyko, F. (2008). Modes of action of the DNA methyltransferase inhibitors azacytidine and decitabine. Int J Cancer, vol.123, No.1, pp.8-13.

Szmigielska-Kapłon, A. \& Robak, T. (2011). Hypomethylating Agents in the Treatment of Myelodysplastic Syndromeas and Myeloid Leukemia. Curr Cancer Drug Targets. (Jun 15). In: PubMed PMID: 21762079.

Tabby, R. \& Issa, J.P. (2010). Cancer Epigenetics. CA Cancer J Clin, vol.60, pp.376-392.

Tan, P.T. \& Wei, A.H. (2011). The epigenomics revolution in myelodysplasia: a clinicopathological perspective. Pathology, vol.43, pp.536-546.

Teofili, L.; Morosetti, R.; Martini, M.; Urbano, R.; Putzulu, R.; Rutella, S.; Pierelli, L.; Leone, G. \& Larocca, L.M. (2000). Expression of cyclin-dependent kinase inhibitor p15(INK4B) during normal and leukemic myeloid differentiation. Exp Hematol, vol.28, No.5, pp.519-526.

Tiu, R.V.; Visconte, V.; Traina, F.; Schwandt, A. \& Maciejewski, J.P. (2011). Updates in Cytogenetics and Molecular Markers in MDS. Curr Hematol Malig Rep, vol.6, pp.126-35.

van Lohuizen, M.; Frasch, M.; Wientjens, E. \& Berns, A. (1991). Sequence similarity between the mammalian bmi-1 proto-oncogene and the Drosophila regulatory genes Psc and $\mathrm{Su}(\mathrm{z}) 2$. Nature, vol.26, No.353(6342), pp.353-355.

Vidal, D.O.; Paixão, V.A.; Brait, M.; Souto, E.X.; Caballero, O.L.; Lopes, L.F. \& Vettore, A.L. (2007). Aberrant methylation in pediatric myelodysplastic syndrome. Leuk Res, vol.31, No.2, pp.175-181.

Vigna, E.; Recchia, A.G.; Madeo, A.; Gentile, M.; Bossio, S.; Mazzone, C.; Lucia, E.; Morabito, L.; Gigliotti, V.; Stefano, L.D.; Caruso, N.; Servillo, P.; Franzese, S.; Fimognari, F.; Bisconte, M.G.; Gentile, C. \& Morabito, F. (2011). Epigenetic regulation in 
myelodysplastic syndromes: implications for therapy. Expert Opin Investig Drugs, vol.20, No.4, pp.465-493.

Welch, G.E. \& Gabbe, S.G. (1996). Review of statistics usage in the American Journal of Obstetrics and Gynecology. Am J Obstet Gynecol, vol.175, pp.1138-1141.

Williams, J.L.; Hathaway, C.A.; Kloster, K.L. \& Layne, B.H. (1997). Low power, type II errors, and other statistical problems in recent cardiovascular research. Am J Physiol, vol.273, pp.4487-4493.

Wong, K.F. \& So, C.C. (2002). Hypoplastic Myelodysplastic Syndrome - a Clinical, Morphologic, or Genetic Diagnosis? Cancer Genetics and Cytogenetics; vol.138, pp.8588.

Worn, J. \& Gulberg, P. (2002). DNA methylation: an epigenetic pathway to cancer and promising target for anticancer therapy. J Oral Pathol Med, vol.31, pp.443-449.

Wu, X.; Liu, W.; Tian, Y.; Xiao, M.; Wu, Y. \& Li, C. (2011). Aberrant methylation of deathassociated protein kinase $1 \mathrm{CpG}$ islands in myelodysplastic syndromes. Acta Haematol, vol.125, pp.179-85.

Xu, F.; Li, X.; Wu, L.; Zhang, Q.; Yang, R.; Yang, Y.; Zhang, Z.; He, Q. \& Chang, C. (2011). Overexpression of the EZH2, RING1 and BMI1 genes is common in myelodysplastic syndromes: relation to adverse epigenetic alteration and poor prognostic scoring. Ann Hematol, vol.90, No.6, pp.643-53.

Zar, J.H. (2010). Biostatistical Analysis. 5th ed. Prentice Hal, New Jersey. 


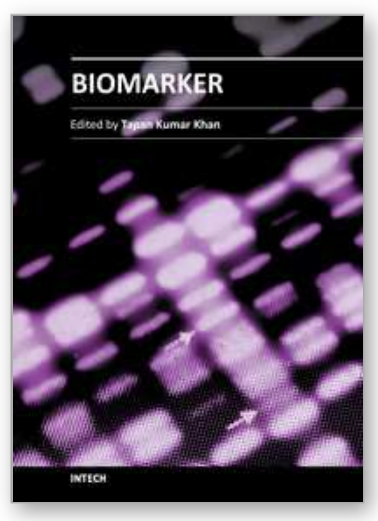

\author{
Biomarker \\ Edited by Prof. Tapan Khan
}

ISBN 978-953-51-0577-0

Hard cover, 392 pages

Publisher InTech

Published online 27, April, 2012

Published in print edition April, 2012

Clinicians, scientists, and health care professionals use biomarkers or biological markers as a measure of a person's present health condition or response to interventions. An ideal -biomarker should have the following criteria: (I) ability to detect fundamental features of the disease, (II) ability to differentiate from other closely related diseases, (III) ability to detect early stages and stages of progression, (IV) the method should be highly reliable, easy to perform and inexpensive, and (V) sample sources should be easily accessible from body. Most of the chapters in this book follow the basic principle of biomarkers.

\title{
How to reference
}

In order to correctly reference this scholarly work, feel free to copy and paste the following:

Teresa de Souza Fernandez, André Mencalha and Cecília de Souza Fernandez (2012). Epigenetics in Cancer: The Myelodysplastic Syndrome as a Model to Study Epigenetic Alterations as Diagnostic and Prognostic Biomarkers, Biomarker, Prof. Tapan Khan (Ed.), ISBN: 978-953-51-0577-0, InTech, Available from: http://www.intechopen.com/books/biomarker/epigenetics-in-cancer-the-myelodysplastic-syndrome-as-amodel-to-study-epigenetic-alterations-as-d

\section{INTECH}

open science | open minds

\section{InTech Europe}

University Campus STeP Ri Slavka Krautzeka 83/A 51000 Rijeka, Croatia Phone: +385 (51) 770447 Fax: +385 (51) 686166 www.intechopen.com

\section{InTech China}

Unit 405, Office Block, Hotel Equatorial Shanghai No.65, Yan An Road (West), Shanghai, 200040, China 中国上海市延安西路65号上海国际贵都大饭店办公楼405单元 Phone: +86-21-62489820

Fax: +86-21-62489821 
(C) 2012 The Author(s). Licensee IntechOpen. This is an open access article distributed under the terms of the Creative Commons Attribution 3.0 License, which permits unrestricted use, distribution, and reproduction in any medium, provided the original work is properly cited. 